\title{
Rare leaf fossils of Monimiaceae and Atherospermataceae (Laurales) from Eocene Patagonian rainforests and their biogeographic significance
}

\author{
Cassandra L. Knight and Peter Wilf
}

\begin{abstract}
Two Eocene fossil sites in Patagonia, Argentina, Laguna del Hunco (ca. 52.2 Ma) and Río Pichileufú (ca. 47.7 Ma), produce some of the most diverse fossil floras known, representing angiosperm-dominated, Gondwanan rainforests. We focus on rare, toothed fossil leaves representing the families Atherospermataceae and Monimiaceae (Laurales), which currently exhibit broad, often disjunct southern distributions and hold much interest for Gondwanan biogeography. For Laurelia guinazui Berry 1935 (Atherospermataceae), we report 24 new specimens and propose reassignment to Atherospermophyllum gen. nov. and $A$. guinazui (Berry) comb. nov. The species was thought to be a South American element of the Eocene floras, but we find that it shows greater similarity to the extant, closely related Australian genera Daphnandra and Doryphora than to Laureliopsis (South America) and Laurelia (South America and New Zealand). Monimiaceae are represented by a single fossil specimen from Laguna del Hunco, here assigned to Monimiophyllum callidentatum sp. nov. This fossil shows greatest similarity to Wilkiea, a derived genus extant in Australia, in apparent contrast with molecular analyses placing the divergence of the Wilkiea clade in Australasia at 16-38 Ma. Thus, the Wilkiea lineage may be older and have a broader biogeographic history across Gondwana. Our findings significantly improve the scarce fossil records for Atherospermataceae and Monimiaceae. The fossils were found at great modern distance from their apparent closest living relatives and, remarkably, with similar associated genera, increasing the links of Eocene Patagonian floras to Australasia and further weakening their surviving signal in extant South American forests.
\end{abstract}

Cassandra L. Knight. Department of Geosciences, Pennsylvania State University, University Park, Pennsylvania 16802 USA knight.cassi@gmail.com

Peter Wilf. Department of Geosciences, Pennsylvania State University, University Park, Pennsylvania 16802 USA pwilf@psu.edu

Keywords: Patagonia; Eocene; Laurales; biogeography; new genus; new species

PE Article Number: 16.3.26A

Copyright: Paleontological Society November 2013

Submission: 20 March 2013. Acceptance: 3 November 2013

Knight, Cassandra L. and Wilf, Peter. 2013. Rare leaf fossils of Monimiaceae and Atherospermataceae (Laurales) from Eocene Patagonian rainforests and their biogeographic significance, Palaeontologia Electronica Vol. 16, Issue 3; 26A; 39p; palaeo-electronica.org/content/2013/546-eocene-laurales-from-patagonia 


\section{INTRODUCTION}

Laurales are an order of magnoliid angiosperms that includes seven families: Atherospermataceae, Calycanthaceae, Gomortegaceae, Hernandiaceae, Lauraceae, Monimiaceae, and Siparunaceae (Renner, 1999; Soltis and Soltis, 2004; Angiosperm Phylogeny Group, 2009). These families are distributed globally and exhibit diverse floral and foliar morphology; the Lauraceae are by far the most diverse, with $>2500$ species vs. one to ca. 195 species in each of the other families (Renner, 2005). Most of the 91 genera of Laurales live in tropical to subtropical climates, and many have distinctly Gondwanan distributions. The Laurales have long been the focus of phylogenetic and biogeographic research (Renner, 1998, 1999; Renner et al., 2000, 2010; Doyle and Endress, 2000; Soltis and Soltis, 2004) because they comprise an earlydiverging lineage of angiosperms, whose fossil record stretches back to the Early Cretaceous (e.g., Drinnan et al., 1990; Herendeen et al., 1994; Friis et al., 1994; Eklund and Kvaček, 1998). The genera in Laurales have also been the focus of many paleobiogeographic studies (e.g., Süss, 1960; Rüffle, 1965; Thorne, 1973; Raven and Axelrod, 1974; Knappe and Rüffle, 1975; Renner, 1998) because they were present in Gondwana before its late break-up during the early-middle Eocene, at which time Australia and South America separated fully from Antarctica (LaGabrielle et al., 2009; Lawver et al., 2011). Thus, the distributions of Laurales genera offer excellent test cases for classic vicariance vs. dispersal hypotheses within the basal (non-eudicot) angiosperms. The fossil record can improve our understanding of how Laurales were distributed in the past and constrain scenarios for how their current biogeography, which includes many disjunct genera, developed through time.

Two Eocene fossil localities, Laguna del Hunco (LH) and Río Pichileufú (RP) in Patagonia, Argentina, preserve exceptionally diverse Southern Hemisphere rainforest floras that contain several lineages of Laurales, including Lauraceae as well as the families studied here (Berry, 1925, 1935, 1938; Wilf et al., 2003, 2005, 2009). These floras are preserved in caldera-lake deposits and indicate a climate similar to that of modern montane subtropical and tropical rainforests (Aragón and Mazzoni, 1997; Wilf et al., 2009; Wilf, 2012). Ashes stratigraphically interbedded with the fossil floras have been ${ }^{40} \mathrm{Ar}-{ }^{39} \mathrm{Ar}$ dated to $52.22 \pm 0.22 \mathrm{Ma}(\mathrm{LH})$ and $47.74 \pm 0.05 \mathrm{Ma}(\mathrm{RP})$, placing them in the globally warm early Eocene Climatic Optimum and early middle Eocene, respectively (Wilf et al., 2003, 2005; Zachos et al., 2008; Wilf, 2012). The exceptional richness of the floras at these sites has been attributed to Eocene warmth, high regional rainfall, and biotic interchange with the remainder of South America to the north and with Antarctica, and thus Australia, to the south (Wilf et al., 2003, 2005, 2009; Wilf, 2012). They are dominated by angiosperms but also contain abundant and diverse conifers as well as ginkgophytes, cycads, and ferns (e.g., Wilf et al. 2005; see below). The floras are of great interest when considering southern biogeography because they contain (in many cases) the only South American records of several lineages whose extant relatives are concentrated many thousands of kilometers away, in tropical and subtropical Australasia. The greatly separated fossil and living ranges inspire questions regarding the location and the timing of origination for these plant lineages, and the subsequent development of their biogeography in the context of primary forcing factors such as plate movement and climate change.

Some elements of the Laguna del Hunco and Río Pichileufú floras were historically assigned to families and genera that are extant today in temperate South America (Berry, 1925, 1935, 1938). Among the conifers, Libocedrus prechilensis Berry 1938 was thought to be related to the Cordilleran Cypress, Austrocedrus (Libocedrus) chilensis (Cupressaceae), which lives in the cold-temperate to Mediterranean climates of southern Argentina and Chile. Fitzroya tertiaria sensu Berry 1938 was considered to represent an extinct relative of the Alerce, Fitzroya cupressoides (Cupressaceae), which inhabits Patagonian temperate rainforests. However, Libocedrus prechilensis was revised to Papuacedrus prechilensis (Wilf et al., 2009), and the Fitzroya tertiaria to Dacrycarpus puertae (Podocarpaceae; Florin, 1940a; Wilf, 2012). Living Papuacedrus and Dacrycarpus are restricted to New Guinea and the Moluccas, and to Australasia and south-east Asia, respectively. Several additional examples illustrate that many more elements of the Patagonian flora than Berry thought are best represented in, or even endemic to Australasia today: Acmopyle (Podocarpaceae; Florin, 1940b) and several other conifers (Wilf et al., in press), the fern Todea (Osmundaceae; Carvalho et al., 2013), and the angiosperms Akania (Akaniaceae; Romero and Hickey, 1976; Gandolfo et al., 1988), Gymnostoma (Casuarinaceae; Zamaloa et al., 2006), and Eucalyptus (Gandolfo et al., 2011; Hermsen et al., 2012). 
Although the number of Australasian connections to the Eocene Patagonian floras continues to increase, a few fossil lineages from RP and $\mathrm{LH}$, such as the angiosperms Orites bivascularis (Proteaceae, LH only; Romero et al., 1988; González et al., 2007) and Laurelia guinazui (Atherospermataceae, LH and RP; Berry, 1935), still suggest affinities to modern floras of southern South America. Orites and Laurelia live in South America and Australasia today, and both genera exhibit large range disjunctions. Orites has nine living species, eight of which are found in temperate Australia, and one of which is found in Argentina (Romero et al., 1988; González et al., 2007). There is a good fossil record of Orites on both continents. In Tasmania, seven fossil species of Orites are reported: three from the early Oligocene and four (three of which are identified as living species) from the Pleistocene (Jordan, 1995; Carpenter and Jordan, 1997; Jordan et al., 1998; Carpenter, 2012). In South America, the fruit Orites bivascularis, from LH, has been placed confidently in the living genus, though not in any subgroups currently endemic to Australia or South America (Romero et al., 1988; González et al., 2007). The genus Laurelia is disjunct between southern South America (L. sempervirens) and New Zealand (L. novae-zelandiae), and Laureliopsis philippiana (nested within Laurelia: Renner et al., 2000) is endemic to southern South America. Berry (1935) stated that the fossil species Laurelia guinazui more closely resembled the extant South American species than the New Zealand species, and living L. philippiana in particular has been noted to show a close resemblance to L. guinazui (Schodde, 1969; Renner et al., 2000). Thus, Laurelia guinazui is one of very few elements of Eocene Patagonian floras that have still been considered to show South American affinities.

Much of modern Patagonia east of the Andes, including the fossil sites, is dry, sparsely vegetated steppe, but the remarkable fossil floras from the region show that Eocene Patagonia had a wet climate with abundant rainfall that supported highly diverse forest ecosystems, with tall canopies dominated by angiosperms and conifers. These rainforests were thriving far south of the equator at paleolatitudes up to $\sim 46^{\circ}$, prior to $(\mathrm{LH})$ or during the initial phases of (RP) the middle Eocene accelerated opening of the Drake Passage and the Tasman Strait. At this time, global climate was warm, including far southern latitudes (Carpenter et al., 2012; Pross et al., 2012), and there were few climatic or geographic barriers to biotic interchange between South America and Australia, via Antarctica (e.g., Lawver et al., 2011).

\section{Biogeography of Extant Atherospermataceae and Monimiaceae}

The genera of Atherospermataceae were once included within Monimiaceae, but differences warranting their familial status have been recognized from both morphological (Schodde, 1969, 1970) and molecular data, which now place the family distant from Monimiaceae within Laurales and sister to the Chilean monotypic genus Gomortega (Renner et al., 1997, 2000; Renner, 1998, 1999). Atherospermataceae and Monimiaceae are predominantly composed of small trees and shrubs that grow in temperate to tropical rainforest environments, typically in montane settings. Both families include genera that exhibit disjunct distributions across the Southern Hemisphere (Figure 1). Atherospermataceae include 16 species in six genera, following the taxonomy of Foreman and Whiffin (2007) but considering Laureliopsis as part of Laurelia. Five genera are found in Australasia (mostly in Australia, but also in New Caledonia, New Guinea, and New Zealand), and one inhabits Chile and Argentina (Figure 1.1; Foreman and Whiffin, 2007). Monimiaceae include ca. 195-200 species in ca. 28 genera, following the taxonomy of Philipson (1987; see also Renner, 1998, 1999; Whiffin and Foreman, 2007; Peixoto and PereiraMoura, 2008). There are currently ca. 10 genera found in Australasia (Australia, New Guinea, New Caledonia, New Zealand), three in Asia (Malaysia, Indonesia, and Sri Lanka), one in Africa, four in Madagascar and surrounding islands, and seven in South America (Figure 1.2; Whiffin and Foreman, 2007; Renner et al., 2010).

For Atherospermataceae, the central biogeographic issues concern the area of origin and whether the disjunction in the Laurelia-Laureliopsis clade (Figure 1.1) resulted from long-distance dispersal events or from vicariance (Renner, 1999; Renner et al., 2000). To address these questions, Renner et al. (2000) constructed a molecular phylogeny for the family and used it along with fossil evidence (two fossil pollen, three leaf, and three wood occurrences) to perform a molecular clock analysis. Their work supported a single disjunction event between southern South America and Australasia in the Laurelia-Laureliopsis clade. They suggested that Atherospermataceae initially diverged in West Gondwana (estimated 100-140 $\mathrm{Ma})$, entered Australia over land via Antarctica, and subsequently colonized New Zealand and 


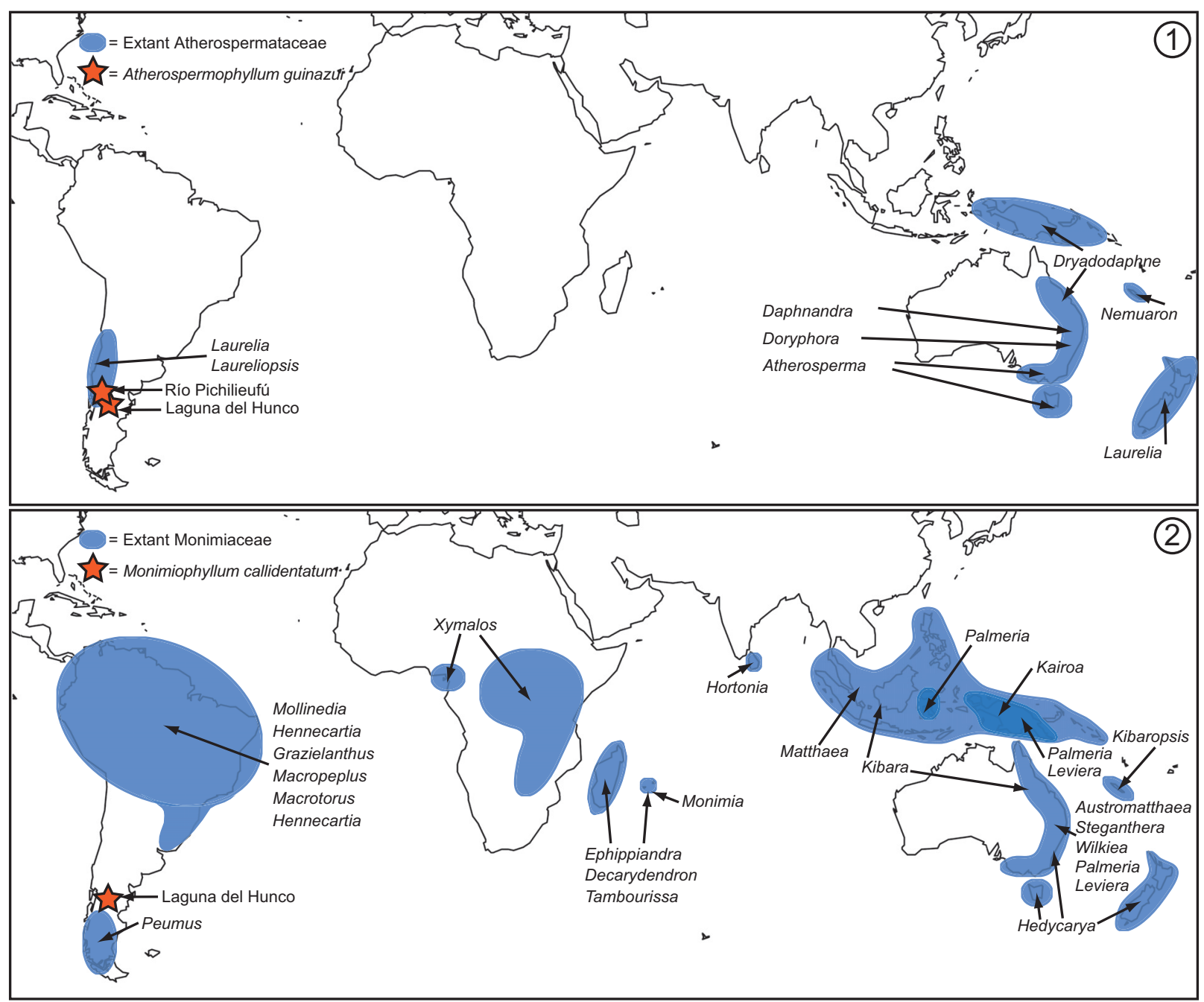

FIGURE 1. Ranges of extant genera in 1 - Atherospermataceae and 2 - Monimiaceae. Extant ranges are indicated by blue fill, and red stars indicate the early Eocene Laguna del Hunco and middle Eocene Río Pichileufú fossil localities, from which Atherospermophyllum guinazui (Berry) comb. nov. and Monimiophyllum callidentatum sp. nov. are here reported. The living ranges of Laurelia-Laureliopsis in South America are close to but do not include the fossil sites, which are located slightly to their east.

New Caledonia by over-water dispersal (ca. 30-50 Ma; Renner et al., 2000).

For Monimiaceae, the current generic distributions throughout the Southern Hemisphere (Figure 1.2) were historically considered to reflect vicariance (Money et al., 1950; Mädel, 1960; Raven and Axelrod, 1974; Lorence, 1985). In contrast, a phylogenetic and molecular clock analysis of Monimiaceae implied that the Australasian genera are young relative to the rest of the family, and that the observed disjunctions are due to relatively recent dispersal events (Renner et al., 2010). Renner et al. (2010) further suggested that the Wilkiea clade (Wilkiea, Kibara, and Kairoa) is one of the youngest groups in the family, that it diverged ca. 16-38
Ma in Australasia, and that many (post-Gondwana) divergence events are attributable to dispersal over water However, few fossils were available to constrain the molecular clock estimates (one leaf and three wood occurrences were used; Renner et al., 2010).

\section{Fossil Records of Atherospermataceae and Monimiaceae}

The macrofossil records of Atherospermataceae and Monimiaceae (Table 1) are exceptionally sparse and notably do not include pre-Pliocene occurrences from Australia. The majority of occurrences are wood specimens (Table 1). Overall, the fossil wood record is more recently reported than 
TABLE 1. Macrofossil records of Atherospermataceae and Monimiaceae.

\begin{tabular}{|c|c|c|c|c|}
\hline Fossil & Organ & Age & Provenance & References \\
\hline \multicolumn{5}{|l|}{ ATHEROSPERMATACEAE } \\
\hline Laurelites jamesrossii Poole and Francis & wood & Campanian & James Ross Island & Poole and Francis, 1999 \\
\hline Protoatherospermoxylon spp. & wood & Late Cretaceous & Cape Province, S.Africa & $\begin{array}{l}\text { Mädel, 1960; Müller-Stoll } \\
\text { and Mädel, } 1962\end{array}$ \\
\hline $\begin{array}{l}\text { Atherospermoxylon bulboradiatum Poole } \\
\text { and Gottwald }\end{array}$ & wood & Paleocene & Seymour Island & Poole and Gottwald, 2001 \\
\hline $\begin{array}{l}\text { Atherospermophyllum guinazui (Berry), } \\
\text { comb. nov. }\end{array}$ & leaves & $\begin{array}{l}\text { Early and middle } \\
\text { Eocene }\end{array}$ & Patagonia, Argentina & $\begin{array}{l}\text { Berry, } 1935,1938 ; \text { this } \\
\text { paper }\end{array}$ \\
\hline Laurelia-like wood & wood & Paleocene-Eocene & Seymour Island & Poole and Gottwald, 2001 \\
\hline Atherospermataceous wood & wood & Late Eocene & Germany & Gottwald, 1992 \\
\hline Laurelioxylon intermedium Nishida & wood & "Tertiary" & Chile & Nishida, 1984 \\
\hline $\begin{array}{l}\text { Atherospermoxylon aegyptiacum (Schenk) } \\
\text { R. Kräusel }\end{array}$ & wood & Early Oligocene & Egypt & Kräusel, 1939 \\
\hline $\begin{array}{l}\text { Laurelites doroteaensis Nishida, H. Nishida } \\
\text { and Nasa }\end{array}$ & wood & Oligocene-Miocene & $\begin{array}{l}\text { Patagonia, Chile and } \\
\text { Argentina }\end{array}$ & $\begin{array}{l}\text { Nishida et al., 1988; Pujana } \\
2009\end{array}$ \\
\hline $\begin{array}{l}\text { Laurelia otagoensis Conran, Bannister and } \\
\text { D.E. Lee }\end{array}$ & $\begin{array}{l}\text { leaves with } \\
\text { cuticle, fruits }\end{array}$ & Early Miocene & New Zealand & Conran et al., 2013 \\
\hline Atherosperma moschatum Labill. & leaves & Pliocene-Pleistocene & Tasmania & Hill and MacPhail, 1985 \\
\hline \multicolumn{5}{|l|}{ MONIMIACEAE } \\
\hline Hedycaryoxylon hortonioides Mädel & wood & Late Cretaceous & Cape Province, S.Africa & $\begin{array}{l}\text { Mädel, 1960; Müller-Stoll } \\
\text { and Mädel, } 1962\end{array}$ \\
\hline $\begin{array}{l}\text { Hedycaryoxylon tambourissoides Poole } \\
\text { and Gottwald }\end{array}$ & wood & Campanian & James Ross Island & $\begin{array}{l}\text { Süss, 1960; Poole and } \\
\quad \text { Gottwald, } 2001\end{array}$ \\
\hline Monimiophyllum antarcticum Zastawniak & leaves & ?Late Paleocene & King George Island & $\begin{array}{l}\text { Birkenmajer and } \\
\text { Zastawniak, } 1989\end{array}$ \\
\hline Monimiophyllum callidentatum sp. nov. & leaf & Early Eocene & Patagonia, Argentina & This paper \\
\hline Flacourtioxylon (Monimiaxylon) gifaense & wood & Late Eocene & Libya & Louvet, 1974 \\
\hline Xymaloxylon (Monimiaxylon) zeltenense & wood & Early Oligocene & Libya & Louvet, 1974 \\
\hline Monimiaceous wood & wood & Early Oligocene & Oman & Privé-Gill et al., 1993 \\
\hline
\end{tabular}

the leaf-fossil record, but it nonetheless offers relatively low taxonomic precision. The oldest known occurrences of atherospermataceous and monimiaceous woods are both Late Cretaceous, from Antarctica and South Africa, respectively, and other reports of woods from these families come from Egypt, Oman, Libya, Germany, and Chile (Table 1).

The leaf macrofossil records for these families are even more scarce. For Atherospermataceae, there are a large number of doubtful occurrences (i.e., fossils that do not exhibit typical characters of the family) from both the Northern and Southern hemispheres (see Schodde, 1969 and Conran et al., 2013 for discussion). Reliable occurrences of the family include Laurelia guinazui from the Eocene of Patagonia, discussed here (Berry, 1935, 1938); Laurelia otagoensis leaves with cuticles, and associated fruits, from the early Miocene Foulden Maar, New Zealand (Conran et al., 2013); and the extant species Atherosperma moschatum from the Pliocene-Pleistocene of Regatta Point, Tasmania (Hill and MacPhail, 1985). In addition, Pole (2008) illustrated several types of Atherospermataceae dispersed cuticles from early Miocene sediments of southern New Zealand, and Lee et al. (2012) illustrated without description a "Laurelialike Atherospermataceae" leaf from the late Eocene Pikopiko flora of Southland, New Zealand. Regarding other occurrences from West Gondwana not listed in Table 1, "Laurelia" amarillana (Berry, 1928, 1937) comes from Late Cretaceous (Berry thought Miocene) sediments of the Mata Amarilla Formation in Santa Cruz Province, Argentina (Berry, 1928; Iglesias et al., 2007; Varela et al., 2012) and, based on our recent inspection of the holotype (USNM 37870), is unlikely to represent Laurelia or Atherospermataceae. "Laurelia" insularis Dusén (1908), from the ?Paleocene of Sey- 
mour Island, Antarctica, is also doubtful. We note that Tosolini et al. (2013) redescribed the single, holotype specimen of "L." insularis and reassigned it to Atherospermataceae sp. We regard this assignment as uncertain because there is no preservation of the leaf base and because the tooth apices are reported to lack glands, despite "excellent preservation of teeth." Laurelia guinazui was first reported from Río Pichileufú by Berry (1935), who assigned it to Monimiaceae. Subsequently, several living genera comprising a former subgroup of Monimiaceae, including Laurelia and Laureliopsis, were shown to be phylogenetically distinct from Monimiaceae and placed in the family Atherospermataceae R. Br. (Renner, 1998, 1999; Renner et al., 2000; Doyle and Endress, 2000). Laurelia guinazui has been noted to exhibit many characteristics now associated with Atherospermataceae and to closely resemble the extant Patagonian rainforest species Laureliopsis philippiana (Schodde, 1969; Renner et al., 2000). The original description and subsequent observations of Laurelia guinazui were made only from the few syntypes (Berry, 1935), but new collections of fossil specimens with better-preserved detail have been made from ongoing field reinvestigations at Laguna del Hunco and Río Pichileufú (Wilf et al., 2005).

Regarding Monimiaceae, the leaf-fossil record consists of two reports: one from the ?Paleocene of Seymour Island that is doubtful and not listed in Table 1 ("Mollinedia" seymourensis Dusén, 1908; also rejected by Tosolini et al., 2013), and one from the ?Paleocene of King George Island, Antarctica (Table 1; Birkenmajer and Zastawniak, 1989). Also, Pole (2008) assigned dispersed cuticles from the early Miocene of southern New Zealand to Hedycarya in the Monimiaceae. No leaf-fossil occurrences for this family have been reported from South America to date.

The goals of this research are to reevaluate $L$. guinazui, to describe a new fossil species of Monimiaceae, and to determine their possible affinities to living taxa in the families Atherospermataceae and Monimiaceae. Reassignment of $L$. guinazui to a genus of Atherospermataceae other than Laurelia-Laureliopsis would effectively remove the generic affinity of another Eocene fossil lineage to modern Patagonia and would support the hypothesis that Eocene floras have left little legacy in the current flora there. Both occurrences have tremendous importance due to the extreme rarity of these families in the fossil record, and the fossil occurrence of Monimiaceae is, so far, unique for South America.

\section{MATERIALS AND METHODS}

\section{Laguna del Hunco and Río Pichileufú}

Laguna del Hunco and Río Pichileufú are fossil caldera-lake sites in Chubut and Río Negro provinces, respectively, Patagonia, Argentina. Their fossil floras were initially reported as Miocene in age (Berry, 1925, 1935, 1938) and later assigned to the Paleocene or Eocene (Archangelsky, 1974; Mazzoni et al., 1991). Extensive field reinvestigations of these localities have been ongoing since 1999, yielding detailed litho- and paleomagnetic stratigraphy, precise ${ }^{40} \mathrm{Ar}-39 \mathrm{Ar}$ dates, and descriptions and revisions of many plant, insect, vertebrate, and ichnotaxa (see Wilf et al. 2003, and Wilf et al. 2009 for a summary). ${ }^{40} \mathrm{Ar}-{ }^{39} \mathrm{Ar}$ analyses of single sanidine crystals from primary ashfall tuffs, stratigraphically associated directly with the most densely fossiliferous horizons, produced the most reliable ages for the floras $(\mathrm{LH}: 52.22 \pm 0.22$ Ma; RP: $47.74 \pm 0.05$ Ma; Wilf et al., 2003, 2005; Wilf, 2012).

\section{Provenance and Repositories}

All fossil material examined in this study is from Laguna del Hunco and Río Pichileufú, and the majority of specimens are from collections made during expeditions from Museo Paleontológico Egidio Feruglio (MEF, repository prefix MPEF-Pb), Trelew, Chubut, Argentina, in 1999, 2002, 2005, and 2009 (e.g., Wilf et al. 2003, 2005; Wilf, 2012). A total of 28 fossil leaf-compression specimens (some carbon remains, but no cuticle preserved) were evaluated: 27 atherospermataceous and one monimiaceous, totaling ca. $0.3 \%$ of the total collection from the sites. Material reported here came from LH quarry sites LH2, LH6, LH13, LH22, LH23, $\mathrm{LH} 25$, and LH27, and the RP3 quarry site of Wilf et al. (2003, 2005) and Gandolfo et al. (2011); the three surviving syntypes of Laurelia guinazui came from RP (Berry, 1935, 1938), precise quarry locations unknown, and are housed at the Smithsonian Institution, National Museum of Natural History (USNM). Specimens from LH are curated at MEF, and recent collections from RP are curated at Museo de Paleontología de Bariloche, Río Negro Province, Argentina (BAR).

\section{Fossil Preparation and Imaging}

Fossil specimens were prepared manually using airscribes and needles, photographed, and scored for morphological characters at the MEF (recent collections) and Pennsylvania State University (L. guinazui syntypes borrowed from USNM). 
TABLE 2. Extant Atherospermataceae species scored.

\begin{tabular}{ll}
\hline \multicolumn{1}{c}{ Species } & \multicolumn{1}{c}{ Range } \\
\hline Atherosperma moschatum Labill. & NSW, Tas, Vic \\
Daphnandra apatela Schodde & NSW, Qld \\
Daphnandra micrantha (Tul.) Benth. & NSW \\
Daphnandra repandula (F.Muell) F. Muell. & NSW, Qld \\
Doryphora aromatica (F.M.Bailey) L.S. Sm. & Qld \\
Doryphora sassafras Endl. & NSW, Qld, Vic \\
Dryadodaphne novoguineensis (Perk.) A.C. Sm. & New Guinea \\
Dryadodaphne trachyphloia Schodde & Qld \\
Laurelia novae-zelandiae A. Cunn. & New Zealand \\
Laurelia sempervirens (Ruiz and Pav.) Tul. & S Chile \\
Laureliopsis philippiana (Looser) Schodde & S Chile and Argentina \\
Nemuaron vieillardii (Baill.) Baill. & New Caledonia \\
\hline
\end{tabular}

Abbreviations: NSW- New South Wales, Tas- Tasmania, Vic- Victoria, Qld- Queensland, Australia.

All macrophotographs were taken using a Nikon D90 camera. At the MEF, microphotographs were taken using a Nikon Digital Sight DSFi1 camera attached to a Nikon Digital Sight DS-L2 control, on a Nikon SMZ1000 dissecting microscope. At Penn State, microphotographs and drawings of the $L$. guinazui syntypes were done using a Nikon SMZ1500 binocular scope with a mounted Nikon DSRi1 camera and camera lucida attachment, and images were processed using Nikon NIS Elements v. 3 software. All photographs and drawings are by CLK.

\section{Extant Material and Characters}

Leaf architectural characters were used as the basis for descriptions, including standard characters (Ellis et al., 2009) as well as additional characters that were determined specifically for Atherospermataceae and Monimiaceae (Appendices 1-5). Both discrete and continuous characters were needed to capture observed variation. Leaf morphology, in the absence of cuticle, can often be used successfully to place compression-impression specimens to family level, and sometimes to generic level (Hickey and Wolfe, 1975; Carvalho et al., 2011). The two fossil species evaluated here were placed in families based on literature analyses (e.g., Hickey and Wolfe, 1975) and our observations of living species because they exhibit several typical characters that are diagnostic in combination. For the fossil Atherospermataceae, these are: low leaf rank and vein density, basally thickened midvein, acute basal secondary veins, weakly brochidodromous secondary veins, and teeth that are 'monimioid' in shape, but unlike those of Monimiaceae species in being typically large, highly irregular, and often compound when two orders of teeth are present. For the fossil Monimiaceae, typical characters are: low leaf rank, a basally thickened midvein, strongly looping secondary veins with the basal pair relatively more acute to the midvein, and distinctive monimioid tooth morphology, which is characterized by an acute apex, acuminate-convex tooth shape, an opaque apical gland cap (darkened on the fossils), and a second- or third-order vein entering the tooth medially (Hickey and Wolfe, 1975). For each family, a matrix of species by characters was constructed. The Atherospermataceae matrix includes 13 species scored using 30 characters (Appendices 1,2), and the Monimiaceae matrix includes 45 species scored using 25 characters (Appendices 1 , $3)$.

The living species evaluated in this study (Tables 2, 3) included, as much as possible, and expanded on those used in the molecular phylogenies of the Monimiaceae and Atherospermataceae by Renner et al. (2000, 2010). Character data came from examination of several herbarium collections and from a small field collection made by C.L.K. in July, 2011 in Border Ranges and Nightcap National Parks, northeastern New South Wales, Australia, housed at the Pennsylvania State University Herbarium (PAC). Herbaria visited included the Gray Herbarium, Harvard University, Cambridge, Massachusetts (GH); the Australian 
TABLE 3. Extant Monimiaceae species scored.

\begin{tabular}{|c|c|}
\hline Species & Range \\
\hline Austromatthaea elegans L.B. Sm. & Qld \\
\hline Decarydendron ranomafanensis Lorence and Razafim. & Madagascar \\
\hline Ephippiandra madagascariensis (Danguy) Lorence & Madagascar \\
\hline Grazielanthus arkeocarpus Peixoto and Per.-Moura & SE Brazil \\
\hline Hedycarya angustifolia A. Cunn. & Qld, Tas \\
\hline Hedycarya arborea J.R. Forst. and G. Forst. & New Zealand \\
\hline Hedycarya cupulata Baill. & New Caledonia \\
\hline Hedycarya loxocarya (Benth.) W.D. Francis & Qld \\
\hline Hennecartia omphalandra Poiss. & S Brazil, NE Argentina, Paraguay \\
\hline Hortonia floribunda Wight ex Arn. & Sri Lanka \\
\hline Kairoa suberosa Philipson & New Guinea \\
\hline Kibara coriacea (Blume) Hook. f. and A. Thomps. & Malaysia \\
\hline Kibara macrophylla (A. Cunn.) Benth. & NSW \\
\hline Kibara moluccana Boerl. ex Perk. & New Guinea, Moluccas \\
\hline Kibaropsis caledonica (Guillaumin) J. Jeremie & New Caledonia \\
\hline Levieria acuminata Perk. & New Guinea, Qld \\
\hline Macropeplus ligustrinus (Tul.) Perk. & SE Brazil \\
\hline Macrotorus utriculatus Perk. & SE Brazil \\
\hline Matthaea sancta Blume & Malaysia, Indonesia \\
\hline Mollinedia ovata Ruiz and Pav. & Ecuador \\
\hline Mollinedia schottiana (Spreng.) Perk. & Brazil \\
\hline Mollinedia widgrenii A. DC. & Brazil \\
\hline Monimia ovalifolia Thouars & Réunion, Mascarenes \\
\hline Monimia rotundifolia Thouars & Réunion, Mascarenes \\
\hline
\end{tabular}

Abbreviations: NSW- New South Wales, Tas- Tasmania, Vic- Victoria, Qld- Queensland, Australia.

National Herbarium, Canberra (CANB); and the National Herbarium of New South Wales, Botanic Gardens Trust, Royal Botanic Gardens, Sydney (NSW). Additionally, several herbarium sheet images were downloaded from the Herbarium of the New York Botanical Garden (NYBG) and the Herbarium Musei Parisiensis (P) (plants.jstor.org; // coldb.mnhn.fr/Consultation?catalogue $=1$ ). Each living genus and species included for analysis was scored using the character matrix described above and in Appendices 1-3. In order to capture the full range of variation exhibited in a species, multiple sheets of each species were scored, and all character values were compiled to yield a representative score.

Similarly, all fossil specimens under investigation were scored with the same suite of characters that we used for the living species in their respective families (Appendices 1-3), and all L. guinazui fossil specimen scores were compiled to capture the full range of variation exhibited by this fossil species (there was only one specimen of fossil Monimiaceae). The compiled fossil species scores were then compared to the representative scores for each living genus and species, using percent similarity to indicate the closest morphological matches phenetically (Tables 4, 5; Appendices 2, $3)$. Percent similarity was calculated using the following method: for each living taxon, individual character scores were coded as matches if the entire range of scores for a character exhibited by the living taxon contained the entire range exhibited by the fossil species ("living contains fossil"). The number of character states coded as matches 
TABLE 3 (continued).

\begin{tabular}{|c|c|}
\hline Species & Range \\
\hline Palmeria foremanii Whiffin & NSW, Qld \\
\hline Palmeria scandens F. Muell. & NSW, Qld \\
\hline Peumus boldus Molina & Chile \\
\hline Steganthera australiana C.T. White & New Guinea \\
\hline Steganthera cooperorum Whiffin & Qld \\
\hline Steganthera hirsuta Perk. & Qld, New Guinea \\
\hline Steganthera laxiflora (Benth.) Whiffin and Foreman & Qld \\
\hline Steganthera macooraia (F.M. Bailey) P.K. Endress & Qld \\
\hline Tambourissa elliptica A. DC. & Réunion, Mascarenes \\
\hline Tambourissa ficus (Tul.) A. DC. & Mauritius, Mascarenes \\
\hline Tambourissa leptophylla (Tul.) A. DC. & Mayotte, Comoros \\
\hline Tambourissa longicarpa Lorence & Madagascar \\
\hline Tambourissa purpurea (Tul.) A. DC. & Mauritius, Mascarenes \\
\hline Tambourissa tau Lorence & Mauritius, Mascarenes \\
\hline Wilkiea angustifolia (F.M. Bailey) Perk. & Qld \\
\hline Wilkiea austroqueenslandica Domin & NSW, Qld \\
\hline Wilkiea hugeliana (Tul.) A. DC. & NSW, Qld \\
\hline Tetrasynandra pubescens Perk. & Qld \\
\hline Wilkiea rigidifolia (A.C. Sm.) Whiffin and Foreman & Qld, New Guinea \\
\hline Wilkiea smithii Whiffin & Qld \\
\hline Wilkiea sp. "Palmerston" & Qld \\
\hline Xymalos monospora (Harv.) Baill. & Bioko, Cameroon \\
\hline
\end{tabular}

were then counted and divided by the total number of characters scored (per taxon) to yield the numerical percent similarity of the living to the fossil taxon. We note that this method excludes many overlaps and near matches that are of potential interest, but in practice we found it to be by far the most consistent procedure. We also note that characters that were not present in a living taxon, namely tooth characters beyond presence and absence of teeth for entire-margined taxa, were simply not scored in that taxon. This had the effect of proportionally increasing the weightings of remaining characters when living taxa were compared to fossils, as noted in Systematic Paleontology. However, we consider presence of teeth to be of primary comparative importance for the toothed fossil leaves reported here, and thus our most detailed comparisons of the fossils were restricted to the toothed living taxa.

The resulting percentages of matching character states are interpreted to indicate which living taxa the fossil species are most similar to phenetically, based on leaf morphology. However, without attached reproductive structures or other additional data, these fossil species can neither be definitively linked to a living genus, nor clearly distinguished from all living genera, although several differences are apparent (see Systematic Paleontology). Thus, we will conservatively interpret that they are both members of extinct genera, although they exhibit clearly recognizable features of the living families, as discussed above.

Lack of reproductive structures and cuticular preservation, and the large amount of homoplasy observed in the leaf morphological characters would lead to an unreliable phylogenetic analysis, with or without the addition of genetic data (Renner et al., 2000, 2010). We note that only one phylogenetic analysis of Atherospermataceae has been done based on morphological characters of both living and a fossil species (Conran et al., 2013). Even though this work made use of data from leaf 
TABLE 4. Percent character similarity of extant Atherospermataceae to Atherospermophyllum guinazui, comb. nov

\begin{tabular}{lc}
\hline \multicolumn{1}{c}{ Taxon } & \%Similarity \\
Genus & \\
Daphnandra & 63 \\
Doryphora & 56 \\
Laurelia & 56 \\
Dryadodaphne & 48 \\
Laureliopsis & 41 \\
Atherosperma & 33 \\
Nemuaron & 26 \\
Species & \\
Daphnandra apatela & 56 \\
Doryphora sassafras & 44 \\
Laureliopsis philippiana & 41 \\
Laurelia sempervirens & 41 \\
Dryadodaphne novoguineensis & 37 \\
Atherosperma moschatum & 33 \\
Dryadodaphne trachyphloia & 33 \\
Daphnandra micrantha & 33 \\
Daphnandra repandula & 33 \\
Doryphora aromatica & 33 \\
Laurelia novae-zelandiae & 26 \\
Nemuaron vieillardii & 22 \\
\hline
\end{tabular}

Notes: Generic scores are a compilation of the constituent species scores. All taxa scored have toothed leaf-margins.

architecture as well as from cuticles and fruits not available here, the results differed considerably from the molecular phylogeny of Renner et al. (2000). In addition, we found it necessary to use both continuous and discrete characters to adequately describe the variation observed in the limited fossil material. In summary, we decided not to pursue a phylogenetic analysis for several reasons, but we provide abundant data for future workers. In order to empirically illustrate leaf-character distribution and homoplasy across each family and the fossils, we plotted character scores on the tips of molecular phylogenies for Atherospermataceae (Renner et al., 2000; Figure 2) and Monimiaceae (Renner et al., 2010; Figure 3).

\section{SYSTEMATIC PALEONTOLOGY}

Order LAURALES Juss. ex Bercht. and J. Presl Family ATHEROSPERMATACEAE R. Br. Genus ATHEROSPERMOPHYLLUM C.L. Knight gen. nov.
Etymology. Derived from the family name, Atherospermataceae, and phyllum, meaning 'leaf' (Greek).

Type Species. Atherospermophyllum guinazui (Berry) C.L. Knight, comb. nov.

Type material. As for the species, due to monotypy.

Additional Material. As for the species, due to monotypy.

Diagnosis. Leaves unlobed and pinnately veined, with a markedly swollen petiole, weakly brochidodromous secondary veins, one or more acute basal pairs of secondary veins, weakly looped exterior tertiary veins, and a toothed margin. Teeth large, irregular, and typically compound, with large, glandular apices.

Description. Leaves are ovate to elliptic, unlobed, and pinnately veined, with the petiole markedly swollen near the insertion point, a basally thickened midvein, and toothed margins. Secondary veins are weakly brochidodromous to eucamptodromous and irregularly spaced, with the basal pair(s) acute. Exterior tertiary veins are weakly looped. Teeth are large, irregularly spaced and sized, and often compound; principal veins are medial and terminate in a large apical gland.

Atherospermophyllum guinazui (Berry) C.L. Knight, comb. nov.

"Laurelia" (Laureliopsis) guiñazui Berry, Wilf et al. (2005: A7)

Laurelia guiñazui Berry, Geological Society of America Special Paper 12: 75 (1938)

Laurelia guinazui Berry, Botanical Gazette 96: 752 (1935)

Etymology and basionym. The basionym, Laurelia guinazui Berry 1935, honored R. Guiñazú, discoverer of the Río Pichileufú flora.

Lectotype. USNM 40403a (Berry 1935, figure 2 right; Berry 1938, plate 19 figure 4; Figures 4.1, $4.2,5.1,5.2,6.2)$.

Syntypes. USNM 40403a (chosen here as lectotype), USNM 40403b (Berry 1935, figure 2 left; Berry 1938, plate 19 figure 1; Figures 4.3, 4.4), and USNM 40403c, from the historic locality at Río Pichileufú, La Huitrera Fm., Río Negro Province, Patagonia, Argentina (middle Eocene).

Additional Material. Laguna del Hunco, Tufolitas Laguna del Hunco, Chubut Province, Patagonia, Argentina (early Eocene). From quarry LH6 of Wilf et al. 2003: MPEF-Pb 6431, MPEF-Pb 6432. From quarry LH13: MPEF-Pb 5636-5646. From quarry LH22: MPEF-Pb 5648, 5649. From quarry LH23: MPEF-Pb 5650, 5651. From quarry LH25: MPEF$\mathrm{Pb}$ 6427-6430. From quarry LH27 (Gandolfo et al., 
TABLE 5. Percent character similarity of extant Monimiaceae to Monimiophyllum callidentatum, sp. nov.

\begin{tabular}{|c|c|}
\hline Taxon & \%Similarity \\
\hline \multicolumn{2}{|l|}{ Genus } \\
\hline Wilkiea^ $^{\wedge}$ & 76 \\
\hline Mollinedia^ & 76 \\
\hline Kibara^ $^{\wedge}$ & 68 \\
\hline Kairoa* & 68 \\
\hline Hedycarya^ & 68 \\
\hline Tambourissa^ & 68 \\
\hline Palmeria & 68 \\
\hline Steganthera^ & 64 \\
\hline Austromatthaea* & 60 \\
\hline Decarydendron & 58 \\
\hline Hortonia & 58 \\
\hline Macropeplus ${ }^{\wedge}$ & 56 \\
\hline Peumus & 53 \\
\hline Hennecartia* & 52 \\
\hline Levieria* & 52 \\
\hline Kibaropsis & 47 \\
\hline Xymalos^ & 44 \\
\hline Monimia & 42 \\
\hline Grazielanthus* & 40 \\
\hline Macrotorus* & 32 \\
\hline Ephippiandra* & 32 \\
\hline Matthaea & 26 \\
\hline \multicolumn{2}{|l|}{ Species } \\
\hline Wilkiea hugeliana* & 76 \\
\hline Kairoa suberosa* & 68 \\
\hline Tambourissa purpurea & 63 \\
\hline Palmeria foremanii & 63 \\
\hline Austromatthaea elegans* & 60 \\
\hline Decarydendron ranomafanensis & 58 \\
\hline Hortonia floribunda & 58 \\
\hline Wilkiea rigidifolia* & 56 \\
\hline Macropeplus ligustrinus* & 56 \\
\hline Steganthera australiana* & 56 \\
\hline Hedycarya cupulata* & 56 \\
\hline Wilkiea smithii & 53 \\
\hline Peumus boldus & 53 \\
\hline Kibara macrophylla* & 52 \\
\hline
\end{tabular}

2011): MPEF-Pb 6425, 6426. Río Pichileufú, La Huitrera Fm., Río Negro Province, Patagonia, Argentina (middle Eocene). From quarry RP3 of Wilf et al. (2005): BAR 4732.

Description. The blade attachment to the petiole is marginal, and the base of the lamina is usually decurrent onto the petiole, which is thickened near the insertion point (e.g., Figure 4.5). Laminar length is 50 to $122 \mathrm{~mm}$, and the laminar I:w ratio

\begin{tabular}{|c|c|}
\hline Mollinedia schottiana* & 52 \\
\hline Mollinedia widgrenii ${ }^{*}$ & 52 \\
\hline Hennecartia omphalandra* & 52 \\
\hline Tetrasynandra pubescens* & 52 \\
\hline Levieria acuminata* & 52 \\
\hline Hedycarya angustifolia* & 52 \\
\hline Hedycarya arborea* & 52 \\
\hline Tambourissa longicarpa* & 48 \\
\hline Steganthera cooperorum & 47 \\
\hline Steganthera hirsuta & 47 \\
\hline Kibaropsis caledonica & 47 \\
\hline Tambourissa elliptica & 47 \\
\hline Tambourissa tau & 47 \\
\hline Tambourissa leptophylla & 47 \\
\hline Wilkiea angustifolia* & 44 \\
\hline Xymalos monospora* & 44 \\
\hline Wilkiea austroqueenslandica & 44 \\
\hline Steganthera macooraia & 42 \\
\hline Palmeria scandens & 42 \\
\hline Monimia rotundifolia & 42 \\
\hline Monimia ovalifolia & 42 \\
\hline Matthaea heterophylla & 42 \\
\hline Kibara coriacea* & 40 \\
\hline Grazielanthus arkeocarpus* & 40 \\
\hline Steganthera laxiflora* & 40 \\
\hline Hedycarya loxocarya* & 40 \\
\hline Wilkiea sp. "Palmerston" & 37 \\
\hline Kibara moluccana & 32 \\
\hline Tambourissa ficus & 32 \\
\hline Macrotorus utriculatus* & 32 \\
\hline Ephippiandra madagascariensis* & 32 \\
\hline Mollinedia ovata* & 28 \\
\hline Matthaea sancta & 26 \\
\hline
\end{tabular}

Notes: Generic scores are a compilation of the constituent species scores.

${ }^{*}$ Genus or species with toothed leaves.

${ }^{\wedge}$ Genus in which some species are toothed.

ranges from 2.2 to $3.3: 1$. The lamina has an elliptic or ovate shape and is medially and basally symmetrical. The base shape varies between straight (cuneate) to more often convex (Figure 4), with the base angle consistently acute. The apex is consistently straight and acute.

Leaf rank is 2 . The primary venation is pinnate. The midvein is basally thickened and tapers apically (Figure 4). Major secondary vein attach- 

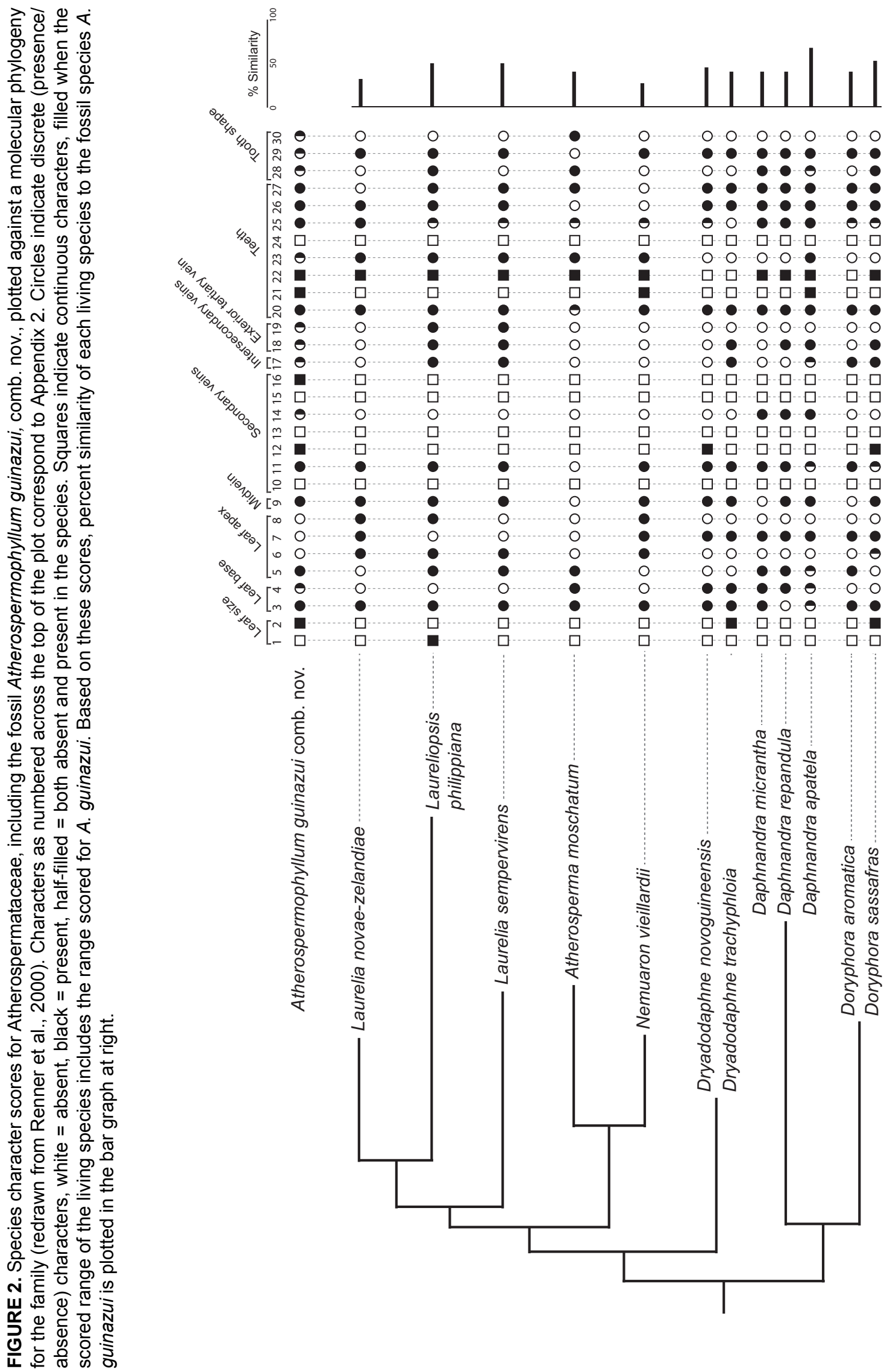


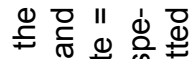

흔

$\geq \frac{0}{3}$.

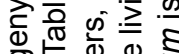

Oัฒ

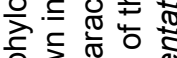

市

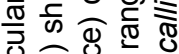

으웡ㅎㅎ

유

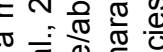

क्ष

䎡过边

히웡

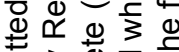

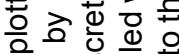

웡 $\frac{0}{2}$

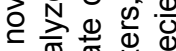

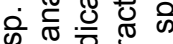

है는

5 의 0

중

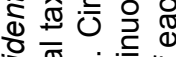

可的部

으을 중

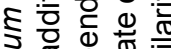

赵

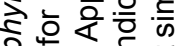

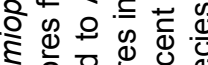

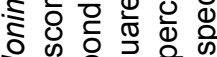

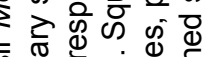

$\overline{\overline{0}}$

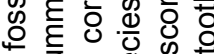

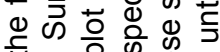

등 क क त

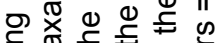

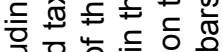

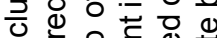

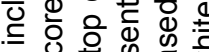

(i)

\&

ष

है

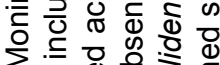

흐웡

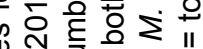

ठัँ

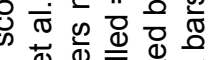

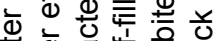

这步

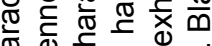

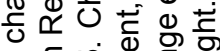

๘

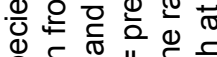

की ऊे

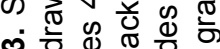

mं 형

崖

䒓츨

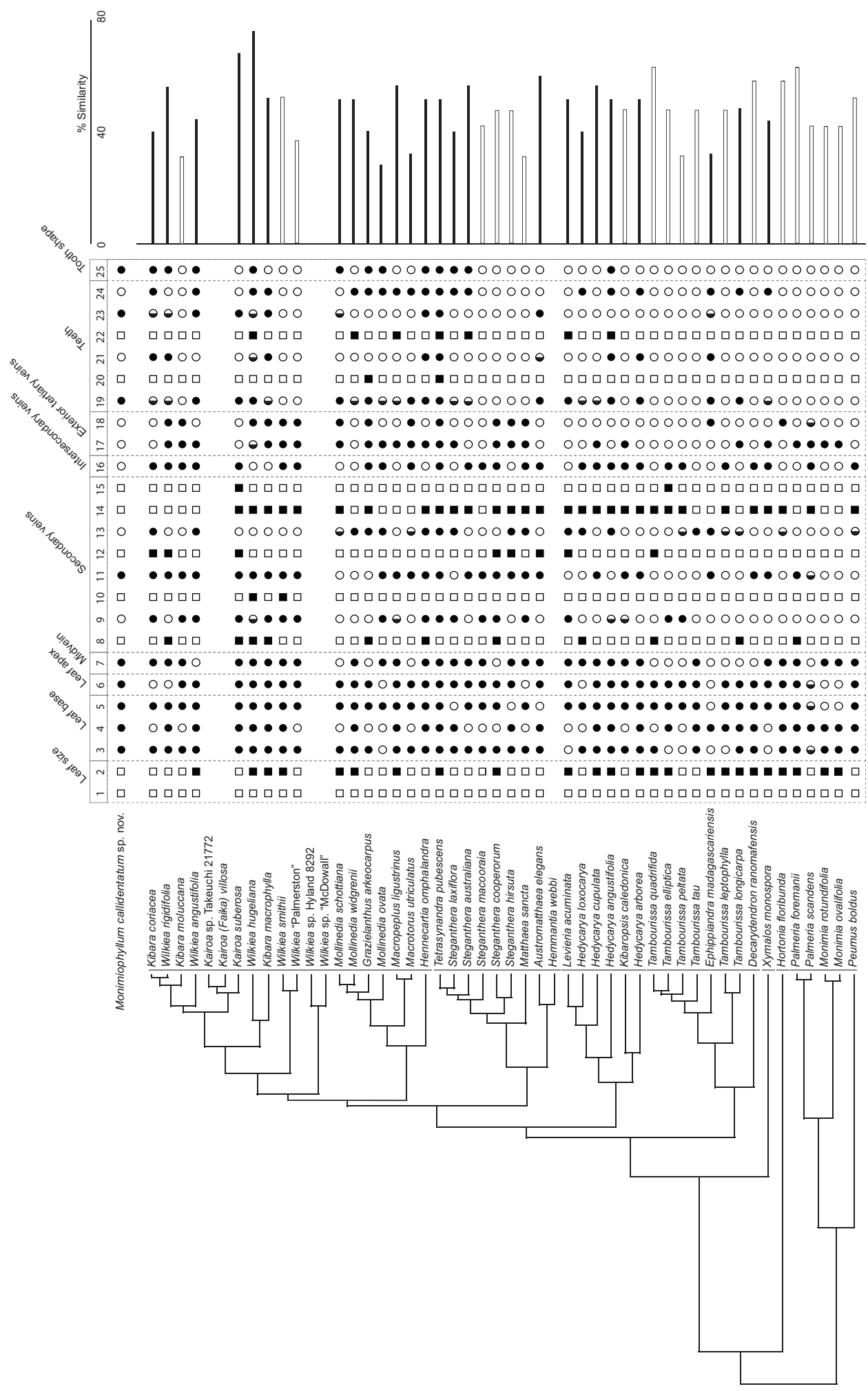

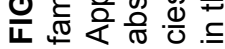




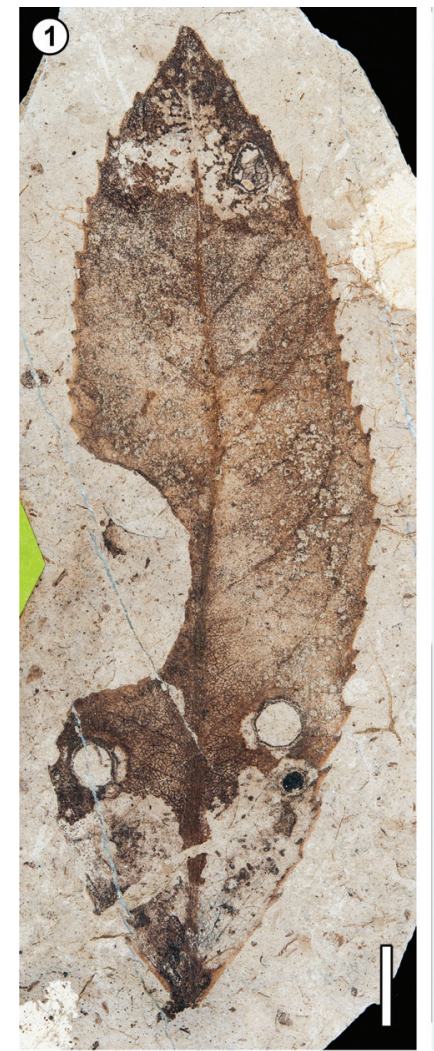

(2)

(6)
)
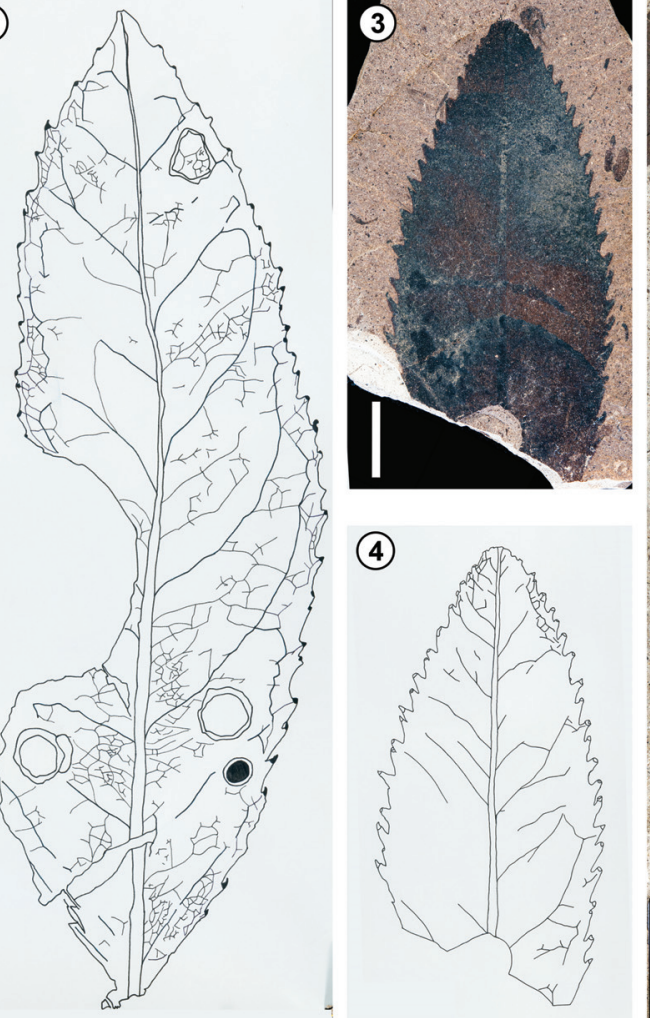

(4)
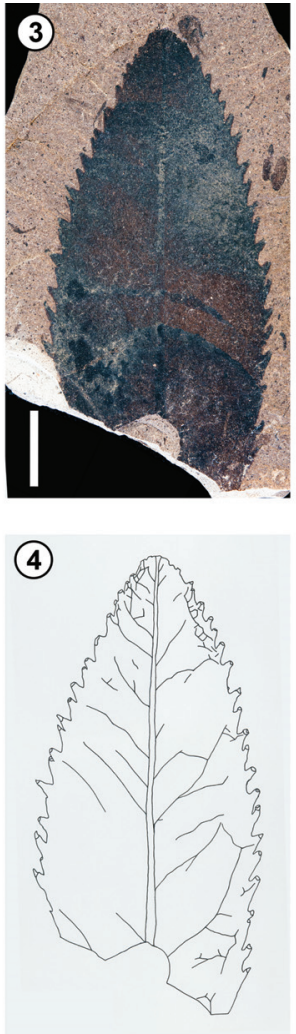
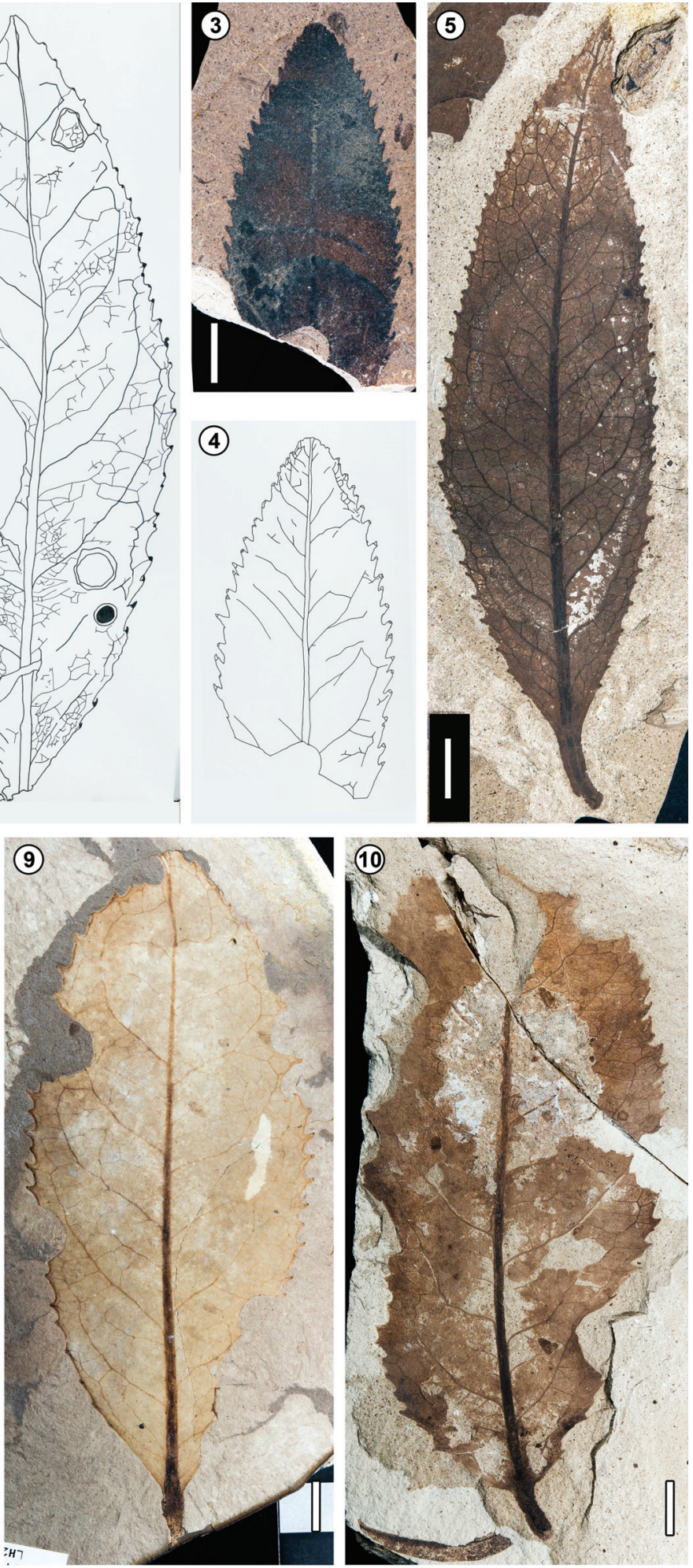

FIGURE 4. Atherospermophyllum guinazui (Berry), comb. nov. 1 - Lectotype, USNM 40403a, from Río Pichileufú (RP); 2 - camera lucida drawing of USNM 40403a, showing venation and tooth details; 3 - USNM 40403b (syntype); 4 - camera lucida drawing of USNM 40403b. Selected new specimens of A. guinazui: 5 - MPEF-Pb 5639 (Laguna del Hunco, LH); 6 - MPEF-Pb 5650 (LH); 7 - MPEF-Pb 5640 (LH); 8 - BAR 4732 (RP); 9 - MPEF-Pb 5648 (LH); 10 MPEF-Pb $5636(\mathrm{LH})$. All scale bars are $1 \mathrm{~cm}$. Also visible on USNM 40403a is extensive insect hole and margin feeding and skeletonization. 

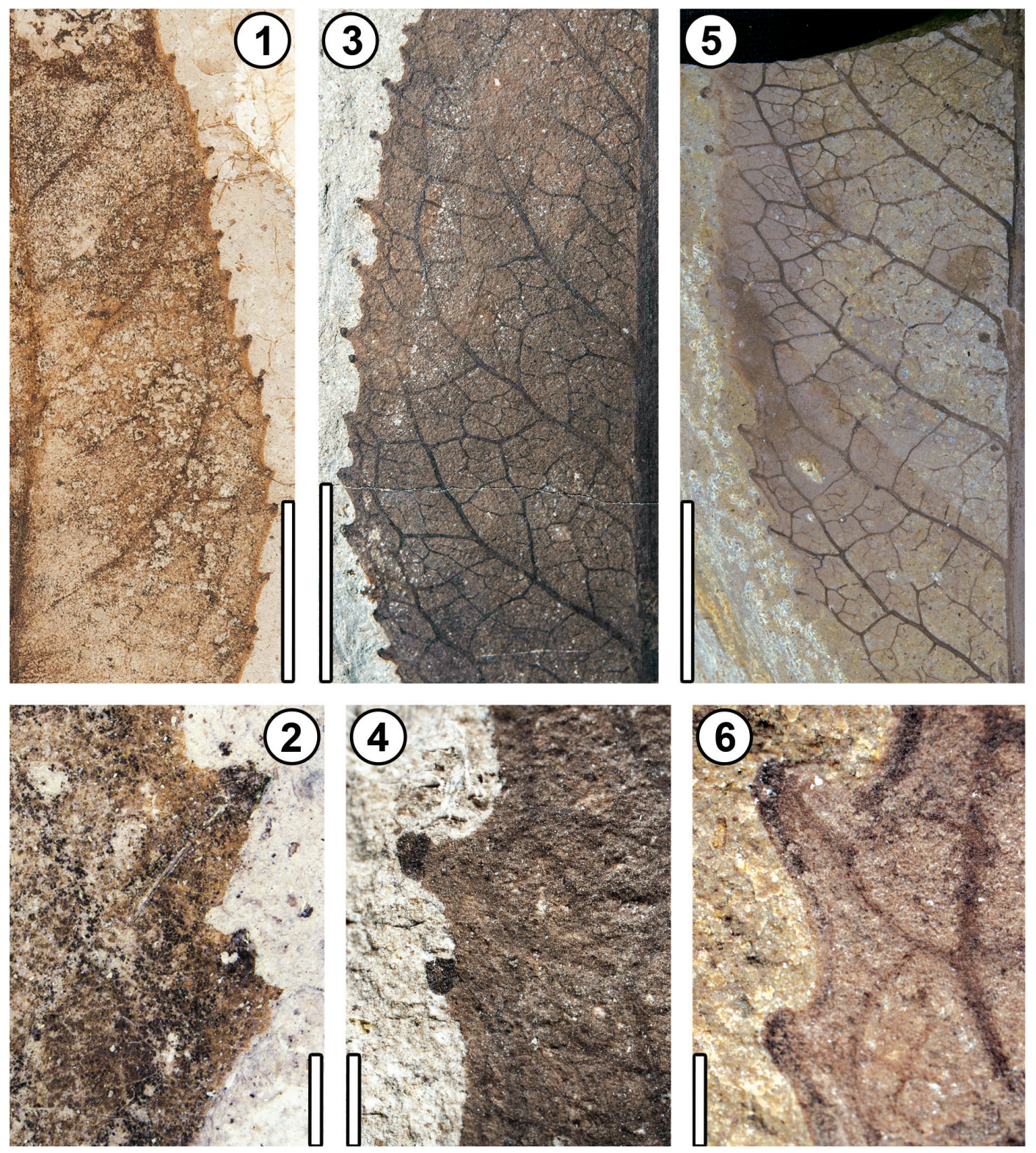

FIGURE 5. Atherospermophyllum guinazui (Berry), comb. nov., venation (1, 3, 5) and tooth (2, 4, 6) details. 1 and 2 USNM 40403a (lectotype, Río Pichileufú); 3 and 4 - MPEF-Pb 5639 (Laguna del Hunco, LH); and 5 and 6 - MPEF-Pb $5641(\mathrm{LH})$. Scale bar is $1 \mathrm{~cm}$ for 1,3 , and 5 , and $1 \mathrm{~mm}$ for 2, 4, and 6 .

ment to the midvein is decurrent. The basalmost pair of secondary veins is typically acute to the midvein (Figure 4), and up to the first three pairs of secondary veins may be acute compared to the remaining secondary veins. The maximum difference between the angle of the basalmost secondary veins to the midvein and that of the second pair of secondary veins is 18 degrees.

Major secondary veins are irregularly spaced and weakly brochidodromous to eucamptodromous (Figures 4,5 ), with the number of secondary loops ranging from 8 to 16 . The ratio of the midvein width to the secondary vein width ranges from 2.75 to 6.43. The secondary veins exhibit varying deflection by tertiary veins (e.g., Figures 4.2, 5.3, 5.5). The loops formed by the secondary veins are variable in shape, size, and strength; some secondaries maintain gauge near the margin (based on these and the stronger exterior tertiaries, the secondary category could be considered festooned semicraspedodromous), whereas others lose gauge and dichotomize or reticulate (e.g., Figure $5.1,5.3,5.5)$. The h:w (height:width) ratio of the secondary loops ranges from 1.47 to 4.33 . The 
proximity (distance) of the secondary vein loops to the blade margin ranges from 4 to $24 \%$ of the total distance from the margin to the midvein (measured perpendicular to the midvein). Intersecondary veins typically occur, and only a few specimens do not exhibit them (MPEF-Pb 5637 and MPEF-Pb 5645). Where present, they occur at a frequency of less than one per intercostal area. The intercostal tertiary vein network is irregular reticulate. Exterior tertiary veins are weakly to very weakly and irregularly looped (e.g., Figure 5.3, 5.5). Fourth and fifth order veins are irregular reticulate.

The blade margin is toothed, and the teeth are large and irregularly spaced, occurring over nearly the full margin excepting the basalmost portion. One or two orders (discrete sizes) of teeth may be present. Some specimens exhibit compound first and second order teeth (Figures 4, 5). The number of teeth per $\mathrm{cm}$ ranges from 2 to 6 . The sinus shape is rounded. The principal veins of the teeth branch from an outermost exterior tertiary, are medial in course, and terminate at the apex in the apical gland (Figure 5). Tooth accessory veins are conjunctal (Figure 5.6). Tooth shapes include concave/straight, concave/retroflexed, and concave/ flexuous (Figure 5). Tooth size, measured as the distance from the sinus to the tooth apex, as a percentage of the distance from the midvein to the tooth apex (both on a single line perpendicular to the midvein), ranges from 3.6 to $11.9 \%$. Tooth apical glands are prominent and flattened at the base, with a bluntly pointed apex (Figure 5). Tooth shape and gland shape are variable overall, but the latter is probably due in part to differences in preservation.

Insect-herbivore damage observed on A. guinazui includes hole feeding, margin feeding, skeletonization, galling, and piercing-and-sucking. The lectotype has especially conspicuous insect damage (Figure 4.1-2).

Notes. Berry (1935, figure 2) designated no type material and illustrated only two specimens (USNM $40403 a$ and $40403 b$ ) of the species, as representing "limits of variation in Laurelia guinazui Berry, sp. nov." It is clear from this caption and his text that the species was based on additional specimens, and any of these that survive, as part of the original gathering of the material supporting the species, are syntypes. We can only verify one additional surviving syntype specimen (USNM 40403c), which was possibly illustrated in a drawing (Berry, 1938, plate19, figure 2), although the drawing does not correspond in detail to the fossil. Berry (1938, plate19, figure 3) also drew what must have been an additional syntype specimen, which is apparently lost.

\section{Discussion: Affinities of Atherospermophyllum guinazui (Berry) comb. nov.}

We interpret $A$. guinazui to show affinity to Atherospermataceae because it exhibits features that, in combination, are stereotypical of the living family, including: low leaf rank and vein density, acute basal secondary veins, weakly brochidodromous secondary veins, and large, glandular, highly irregular, compound teeth. However, several features of $A$. guinazui are distinct from living taxa of Atherospermataceae, requiring the new genus. The tooth apical glands are typically larger than those observed on living species, and no extant species match these fossils in the following characters: ratio of the midvein width to secondary vein width, proximity of the secondary loops to the blade margin, h:w ratio of the secondary loops, number of secondary loops, strength of the tertiary loops, and tooth size (Appendices 2, 3).

Nevertheless, the fossils have many similarities to living taxa. We find that $A$. guinazui most closely resembles (in decreasing order of similarity) the living species Daphnandra apatela, Doryphora sassafras, Laureliopsis philippiana, Laurelia sempervirens, and Dryadodaphne novoguineensis (Table 4; Figure 6). Of these, only Laureliopsis philippiana and Laurelia sempervirens are South American. These compared taxa are phylogenetically well-dispersed across the family, although the two most similar species are in the molecular clade comprised of Daphnandra and Doryphora, which together are sister to the rest of the family and thus are the genera least related to the living South American species (Figure 2).

Daphnandra apatela has by far the highest scored similarity to A. guinazui (Figure 2; Table 4) but differs in having a less swollen petiole and, usually, a markedly concave base. However, there are examples of $D$. apatela with straight and even slightly convex bases that are similar to those seen in the fossils (Figure 6.4-6). Like D. apatela, A. guinazui exhibits a basally thickened midvein and compound teeth. The tooth shapes and sizes of $D$. apatela, and their conspicuous irregularity, are very similar to the fossils (Figure 6.1-6); D. apatela exhibits the most irregular teeth of any species examined in the family.

Doryphora sassafras (Figure 6.7-9) is similar to the fossils in having a swollen petiole and a basally thickened midvein, and in its acute basal secondaries, but it differs noticeably in the appear- 

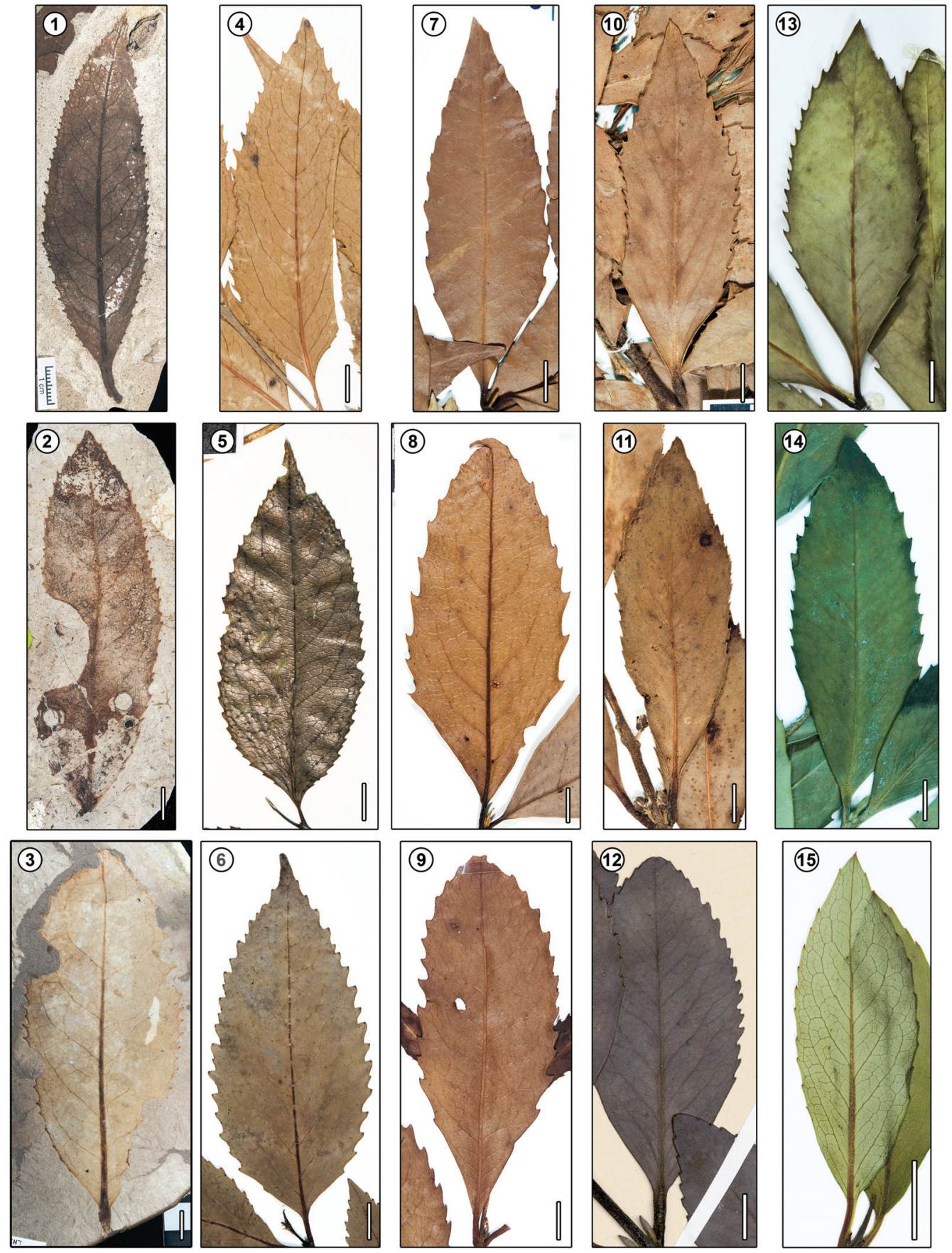

FIGURE 6. Atherospermophyllum guinazui (Berry), comb. nov., exemplars and visual comparisons to living Atherospermataceae species (Figure 2, Table 4). The left column (1-3) shows fossil specimens (Figure 4), and the four other columns, left to right, each show herbarium specimens of Daphnandra apatela (4-6), Doryphora sassafras (7-9), Laureliopsis philippiana (10-12), and Laurelia sempervirens (13-15). Fossil specimens: 1 - MPEF-Pb 5639 (LH); 2 USNM 40403a (lectotype, RP); and 3 - MPEF-Pb 5650 (LH). Examples of living Daphnandra apatela: 4 - NSW 67890, C. Moore 167, Richmond River, NSW, Australia; 5 -CANB 128677, R. Schodde 3366, Sarabah Range, QId., Australia; and 6 - NSW 102541, R. Schodde 5123, Doyle's River State Forest, NSW, Australia. Doryphora sassafras: 7 - NSW 67954, F. M. Bailey, NSW, Australia; 8 - NSW 69329, R. Schodde 3199, Williams River, NSW, Australia; and 9 - CANB 00467700, P. Martensz 222, Mt. Keira, NSW, Australia. Laureliopsis philippiana: 10 - NSW 67915, A. Castellanos, Lago Menéndez, Argentina; 11 - NSW s/n, B.J. Wallace 239/85; and 12 - NSW 67915, A. Castellanos, Lago Menéndez, Argentina. Laurelia sempervirens: 13 - GH s/n, T. Plowman 2618, Isla Tenglo, Chile; 14 - GH s/n, A.L. Cabrera 6026, Laguna Frias, Argentina; and 15 - NSW 618673, J. Allen s/n, cultivated, Mt. Tomah, NSW, Australia. Scale bars are $1 \mathrm{~cm}$. 
ance of the teeth and in the overall venation pattern. The teeth on $D$. sassafras are visibly larger than those on the fossils and are more widely spaced. The teeth also have prominently rounded apices in some cases, whereas the tooth apices are much more pointed in the fossils. Some examples of this species have teeth that are less rounded, and therefore are more similar to the fossil. However, $D$. sassafras lacks compound teeth, which are a very distinctive characteristic of $A$. guinazui. The secondary venation in $D$. sassafras appears to be more prominent (of higher and more consistent gauge) than in the fossils, especially near the margin where the secondary veins recurve.

Laureliopsis philippiana (Figure 6.10-12) differs from the fossils in the acuteness of the basal secondaries, the secondary venation near the leaf margins, and the overall tooth shape. The basalmost secondary veins in $L$. philippiana are less acute than those of the fossils, and they appear to run in a straighter course between the midvein and the margin. The secondary veins of $L$. philippiana curve distinctly upwards near the margin, are more branched near the margins, and do not loop back on themselves so strongly as the secondaries in the fossil species. The teeth of $L$. philippiana typically are slightly more convex on their proximal flanks than the teeth on many of the fossils. However, L. philippiana does show several similarities to the fossils, including a swollen petiole, a basally thickened midvein, and compound, relatively small teeth.

Laurelia sempervirens differs from the fossils in having less acute basal secondaries, secondary vein loops that end less proximally to the margin, and in the shape of the teeth. The teeth of $L$. sempervirens are typically more rounded overall than those of the fossils, especially the tooth proximal flank, which appears more concave or strongly retroflexed (Figure 6.5, 6.13-14; some specimens of $L$. sempervirens have teeth that exhibit a more acute apex and narrower overall shape: Figure 6.15). Like the fossils (and Laureliopsis philippiana), L. sempervirens leaves arise from swollen petioles and have basally thickened midveins and compound teeth.

Among the leaf architectural characters used in their morphological phylogeny of the Miocene fossil Laurelia otagoensis and living Atherospermataceae (along with many epidermal and fruit characters not applicable to our material), Conran et al. (2013) noted the following as clade-specific features: 1) no distinctive features for the South Amer- ican species Laurelia sempervirens and Laureliopsis philippiana; 2) secondary vein angles mostly $>45^{\circ}$ and cuneate leaf bases for the New Zealand fossil Laurelia (new sp.) and living $L$. novae-zelandiae; and 3) secondary vein angles $>45^{\circ}$, acute leaf apices and shallowly undulate margins for the rest of the family. The Patagonian fossil Atherospermophyllum guinazui (Figure 4) has secondary vein angles mostly $>45^{\circ}$, mostly convex (presumably equivalent to "rounded" per Conran et al., 2013) bases, acute leaf apices, and "prominently crenate to serrate" (wording of Conran et al.) margins. Under this scheme, $A$. guinazui would clearly be placed in the third abovementioned group, i.e., excluding the living South American and New Zealand species and, agreeing with our analysis, would be most consistent with the Australian genus Daphnandra (and secondarily with Doryphora). The only apparent conflict with Daphnandra is margin state; however, for this genus, Conran et al. scored Daphnandra tenuipes, which indeed has "shallowly undulate" margins, whereas $D$. apatela has "prominently crenate to serrate" margins (and is consistent in the other character states listed here; Figure 6.4-6). Thus, an independent character set (Conran et al., 2013) validates our result: Australian Daphnandra apatela is the most similar living species to the Patagonian Eocene fossil Atherospermophyllum guinazui.

Family MONIMIACEAE Juss., nom. cons. Genus MONIMIOPHYLLUM Zastawniak, Bulletin of the Polish Academy of Sciences, 37: 82 (1989) Monimiophyllum callidentatum C.L. Knight, sp. nov. "Morphotype TY027, unknown dicot sp." Wilf et al. (2005: A7)

Etymology. This fossil species is named for its distinctive teeth. "Calli-" derives from kalos (Greek, beautiful) and "dentatum" from dentes (Latin, teeth). No living species of Monimiaceae examined here exhibits comparably closely-spaced teeth, which are the most notable feature of this fossil species.

Holotype. MPEF-Pb 5630 (Figures 7, 8.1), Laguna del Hunco, Tufolitas Laguna del Hunco, Chubut Province, Patagonia, Argentina (early Eocene), from quarry LH2 of Wilf et al. (2003).

Diagnosis. Leaf oblong, pinnate, midvein basally thickened. Secondary veins irregularly spaced and semicraspedodromous, the basalmost pair distinctly acute to the midvein. Blade margin toothed with one order of teeth; teeth small, slightly irregular, and very closely spaced. Tooth shape distinctly monimioid, with the principal vein running through 

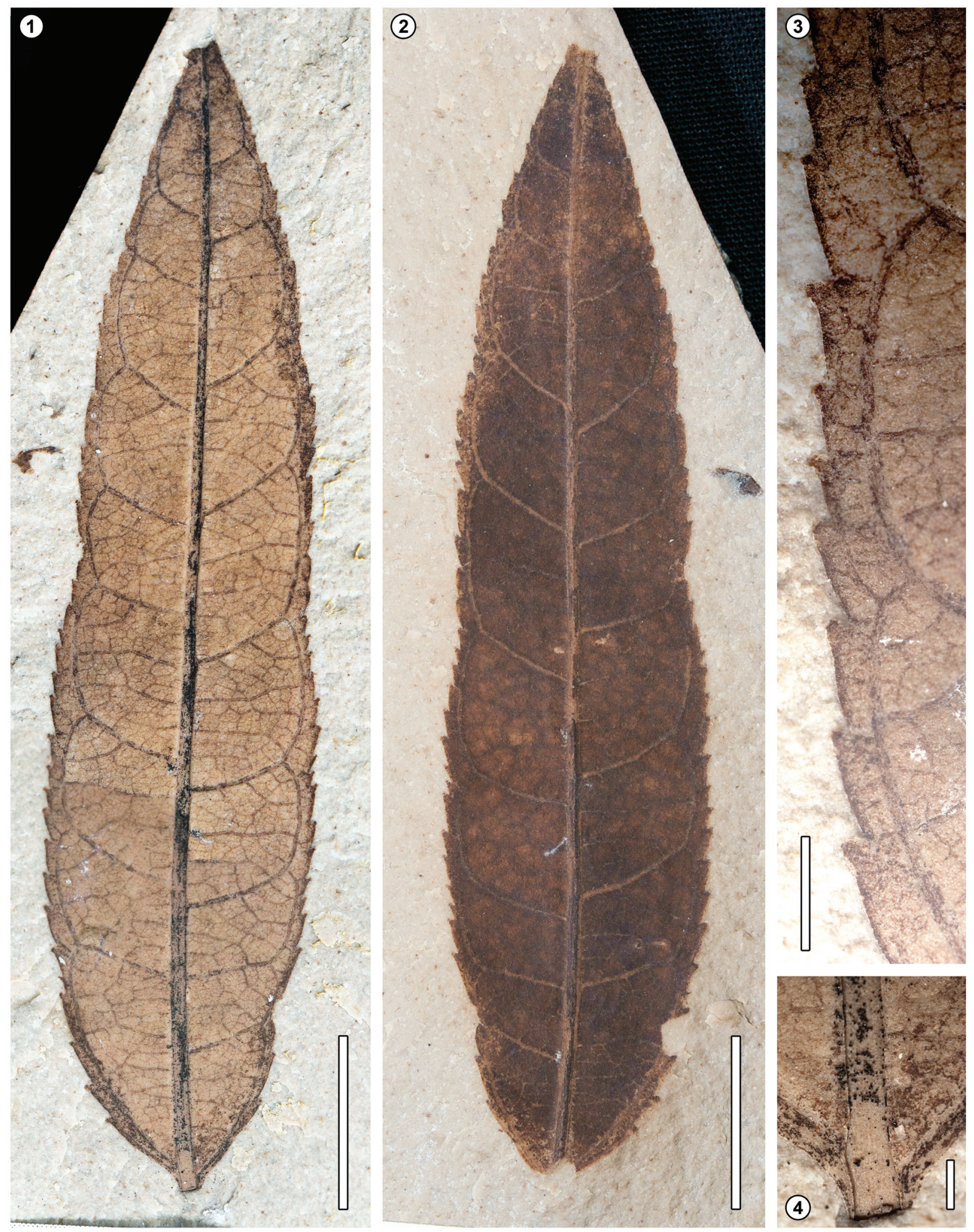

FIGURE 7. Monimiophyllum callidentatum, sp. nov., holotype, MPEF-Pb 5630 (Laguna del Hunco), part and counterpart (1 and 2), and details of the toothed margin (3) and the base (4). Note the deep midvein impression visible on the counterpart. Scale bar is $1 \mathrm{~cm}$ for 1 and 2 , and $1 \mathrm{~mm}$ for 3 and 4 . 


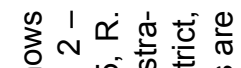

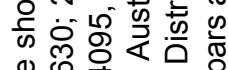
g

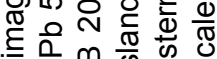

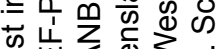
ह

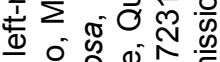

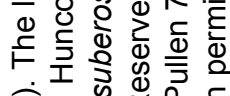
in $\overline{0}$ क⿺辶一

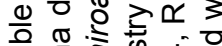

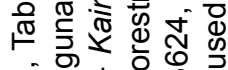
\% 空

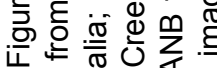

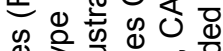
造 응 分

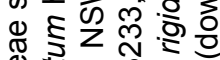
ర্ত ह

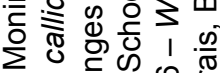

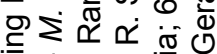

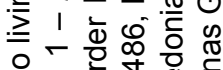
थ ఝ

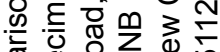

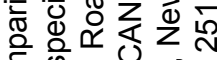
है क

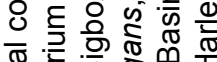
कั চิ

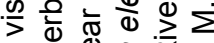
믈 ฮ

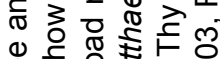
ฉ 응 ॠ ठें बर ำ

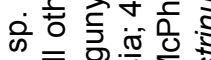
हंत क्रे क्ष $\sum$

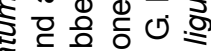
ब

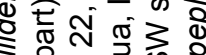

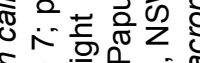
ई

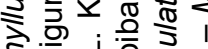

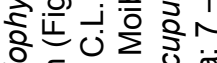

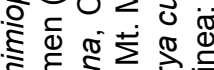
ปิ

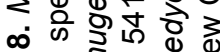

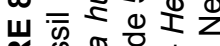

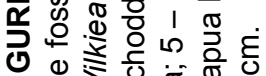
믈
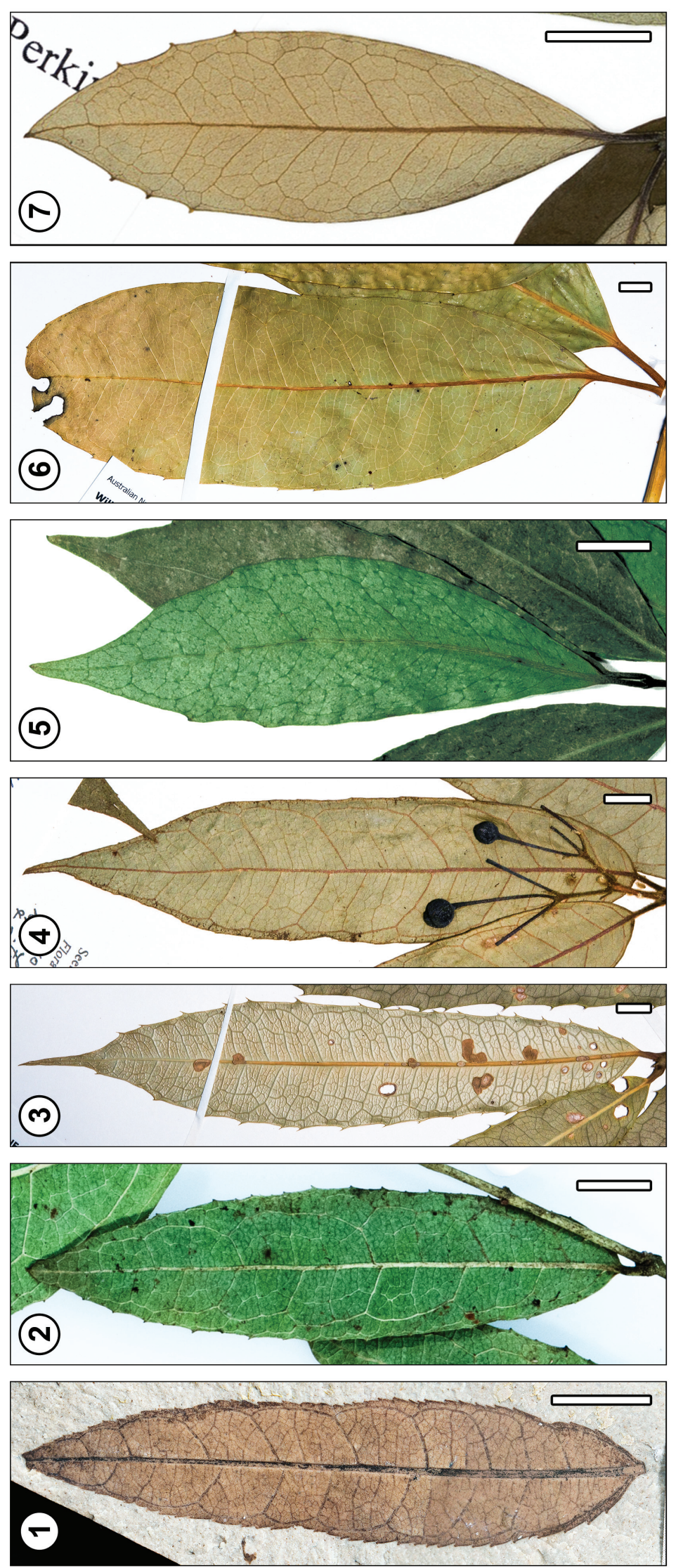
the center of the tooth and terminating at the tooth apex in a large, darkened gland.

Description. Monimiophyllum callidentatum is based on a single fossil specimen of an oblong leaf (Figures 7, 8.1). The laminar length is $66 \mathrm{~mm}$, and the laminar I:W ratio is $4.6: 1$. Leaf attachment is petiolate and blade attachment to the petiole marginal. The lamina is medially and basally symmetric. The base shape is convex, and the base angle is acute. The apex shape is straight, and the apex angle is acute. Leaf rank is 2 . The primary venation is pinnate. The midvein is basally distinctly thickened and tapers toward the leaf apex (Figure 7). Major secondary attachment to the midvein is excurrent, and the angle of attachment is uniform (not including the basalmost pair). The basalmost pair of secondary veins is significantly more acute to the midvein, relative to the other secondary veins (Figure 7). The maximum difference between the angle of the basalmost secondary veins to the midvein and that of the second pair of secondary veins is $30^{\circ}$ (the angles of the left and right basal secondary veins are $25^{\circ}$ and $30^{\circ}$, respectively).

The major secondary veins are irregularly spaced and semicraspedodromous, without festoons. There are 12 strong secondary loop pairs present, not deflected by the tertiary veins. The secondary loop shape maintains a relatively constant width as it approaches the blade margin, and the intercostal fields have a squarish appearance (Figure 7); loops occur at a distance from the margin that is 8 to $13 \%$ of the total distance from the margin to the midvein (measured perpendicular to the midvein). The intercostal tertiary vein fabric is irregular reticulate. Some of the epimedial tertiaries are robust, reaching the distal secondary loops and giving the appearance of intersecondary veins. Exterior tertiary veins enter teeth directly from the secondaries or form weak, irregular loops (Figure 7 ). Fourth and fifth order veins are irregular reticulate.

The blade margin is toothed, with one order of teeth present. Teeth are distributed over the full blade margin except the basalmost portion. The tooth spacing is very close, with 5 to 9 teeth per $\mathrm{cm}$, and is slightly irregular. The sinus shape is angular. The tooth shape is concave/flexuous, and the teeth are distinctly monimioid in morphology, meaning that they have acute apices, medial principal veins (here as exterior tertiary veins), no accessory veins, and distinct, glandular caps (cassidate; Figure 7; Hickey and Wolfe, 1975). Tooth size, measured as the distance from the sinus to the tooth apex, as a percentage of the distance from the midvein to the tooth apex (both on a single line perpendicular to the midvein), ranges from 5.0 to $7.1 \%$.

\section{Discussion: Affinities of Monimiophyllum callidentatum sp. nov.}

The genus Monimiophyllum Zastawniak was diagnosed as "leaves simple, narrow-oblong, margin serrate, tooth-type monimioid, texture coriaceous, venation pinnate, semicraspedodromous" (Birkenmajer and Zastawniak, 1989, p. 83). Monimiophyllum callidentatum sp. nov. fits this diagnosis. The other, type species of the genus, Monimiophyllum antarcticum from Fildes Peninsula, King George Island, Antarctica, early Paleogene (Birkenmajer and Zastawniak, 1989), is clearly distinct from $M$. callidentatum because it has more dispersed teeth and irregular (not regular) secondary veins that are also deflected at tertiary junctions. The new species is assigned to the Monimiaceae because it exhibits typical characters for the family: low leaf rank, a basally thickened midvein, strongly brochidodromous secondary veins with the basal pair relatively more acute to the midvein, and distinctive monimioid tooth morphology.

Keeping in mind that it is represented by a single fossil only, Monimiophyllum callidentatum sp. nov. most closely resembles (in decreasing order of similarity) the toothed living species Wilkiea hugeliana, Kairoa suberosa, Austromatthaea elegans, Hedycarya cupulata, W. rigidifolia, Macropeplus ligustrinus, and Steganthera australiana (Table 5; Figures 3, 8). These taxa are phylogenetically dispersed within the family, but importantly, the two species that are by far the most similar (Wilkiea hugeliana and Kairoa suberosa) belong to the same, derived molecular clade (Figure 3). Palmeria foremanii, Tambourissa purpurea, Hortonia floribunda, and Decarydendron ranomafanensis are excluded from the discussion because they are not toothed, although their similarity in other characters is nevertheless of interest. Their high percent similarity to the fossil species is due to the proportionally increased weighting of non-tooth (venation) characters, as discussed above. We also note that other toothed species related to Wilkiea from Australia and New Guinea that were not scored here (e.g., Hyland et al. 2002; Renner and Takeuchi, 2009) show similarities to the fossil M. callidentatum (based on published illustrations), although none is so convincing as $W$. hugeliana.

Wilkiea hugeliana and $M$. callidentatum (Figures 8.1-2) have ovate to elliptic laminae, basal 
secondary veins at greater than $30^{\circ}$ difference in angle to the superjacent secondary veins, secondary veins that remain parallel between the midvein and the margin to create a secondary loop with an angular appearance, and teeth that are similar in shape and size. Wilkiea hugeliana is one of only two species in the family Monimiaceae seen that have basal secondary veins with an angle as steep as that in the fossil (Figure 8.2; the other, $W$. smithii, has an entire margin, not shown). One characteristic of $W$. hugeliana is the prominently raised veins on the leaf abaxial surface (e.g., Figure 8.2). This feature can be observed in the fossil specimen, which has visibly negative space in the matrix where the veins on the abaxial surface were formerly impressed (Figure 7.2), indicating that they were raised significantly in life. Two characters differ distinctly between the fossil $M$. callidentatum and living $W$. hugeliana. First, the secondary veins of the fossil loop exceptionally close to the margin, more so than $W$. hugeliana, so that there is no space for festoons. Second, $W$. hugeliana has teeth that are less closely spaced than those of $M$. callidentatum, typically with one fewer tooth per centimeter of margin.

Kairoa suberosa (Figure 8.3) primarily resembles the fossil in the shape of the secondary loops and their proximity to the leaf margin. However, the secondary veins of $K$. suberosa are much more deflected by tertiary vein junctions than those of the fossil. Kairoa suberosa also differs from the fossil in its consistently larger leaves, the decurrent attachment of the secondaries to the midvein, a lower number of teeth per $\mathrm{cm}$, less acute basal secondaries, and differing tooth shapes. The teeth of $K$. suberosa have proximal flanks that are concave to straight, whereas $M$. callidentatum exhibits flexuous proximal flanks.

Austromatthaea elegans (Figure 8.4) shows a marked overall similarity to the fossil. It is particularly similar in its prominent midvein, the path of the tertiary venation (there are a few prominent epimedial tertiaries in each intercostal area, whereas all other tertiaries are irregular reticulate), and most especially in the secondary venation. The secondary veins of both $M$. callidentatum and $A$. elegans run smoothly, without deflection, and loop very closely to the blade margin; this is one of the few species of living Monimiaceae with secondary veins that loop as closely to the blade margin as those of the fossil. Austromatthaea elegans differs from the fossil in that it exhibits a lower frequency of teeth, has basal secondary veins that are parallel (not acute) to the superjacent secondary veins, and exhibits different tooth shapes. Instead of being flexuous as in the fossil, the proximal flanks in $A$. elegans are typically straight or concave. The most conspicuous difference between this species and the fossil is its lack of acute basal secondary veins.

Hedycarya cupulata (Figure 8.5) differs most noticeably from the fossil species in the lesser acuteness of the basal secondaries, which reach a maximum angle of difference from the superjacent pair of secondary veins of only $20^{\circ}$ (compared to $30^{\circ}$ in $\mathrm{M}$. callidentatum), the lesser proximity of the secondary loops to the margin, the stronger (higher gauge) exterior tertiary veins, and presence of different tooth shapes. The similarities between $H$. cupulata and the fossil are the overall leaf morphology (acute apex and an acute, convex base) and the configuration of the secondary vein loops. Like the fossil, $H$. cupulata has secondary loops that maintain a relatively consistent width towards the blade margin and are slightly squarish in their appearance.

Wilkiea rigidifolia (Figure 8.6) is different from the fossil in that it has an obtuse (not acute) base, the basal secondaries are less acute, the exterior tertiary loops are stronger and more regular, the teeth are smaller, and it has fewer teeth per $\mathrm{cm}$. This species resembles the fossil in the proximity of the secondary loops to the blade margin, the consistent width of the secondary loops, and in the tooth shapes.

Macropeplus ligustrinus (Figure 8.7) differs from the fossil in having secondary veins that typically loop further from the margin, basal secondaries that are not as acute, a lower number of teeth occurring per $\mathrm{cm}$ with teeth absent in the basal quarter of the blade, and different tooth shapes. Monimiophyllum callidentatum has teeth with flexuous proximal flanks, but $M$. ligustrinus has straight to concave proximal tooth flanks, which is a visually striking difference between the two species. The secondary and tertiary venation also appear dissimilar to the fossil because the secondary veins are highly deflected near the leaf margin and are less regular in their occurrence, and the exterior tertiary loops are stronger.

Steganthera australiana (not shown) differs from the fossil in its consistently larger leaf size, secondary veins that consistently loop further from the blade margin than those of the fossil, basal secondaries that are less acute, lower frequency of teeth, and lack of teeth in the basal quarter of the blade. The secondary and tertiary venation differ from those of the fossil in that the secondaries are 
more deflected, and the tertiary network appears to be much denser.

\section{DISCUSSION}

The well-dated specimens of Monimiaceae and Atherospermataceae reported here are the only known non-wood fossils (for Atherospermataceae) or fossil of any type (Monimiaceae) for these families in South America, and they are among very few fossil examples worldwide (Table 1). They offer new insights into the timing and locations of clade origin, the paleobiogeography of the families, and the paleoecology of Eocene forests in Patagonia.

\section{Atherospermophyllum guinazui (Berry), comb.} nov.

The features of early and middle Eocene $A$. guinazui confirm the presence of Atherospermataceae in South America as early as $52.2 \mathrm{Ma}$, but they do not strongly support assignment to any living genus, including those with extant South American ranges that were previously considered its close relatives and that grow in close proximity to the fossil sites (Laurelia-Laureliopsis; Figure 1). The fossil species instead shows greater morphological similarity to Australasian taxa that are distantly related to the South American species, especially the Australian endemic Daphnandra apatela (Table 4). This result removes another historical link between the Eocene and extant floras of Patagonia, adding to the evidence supporting significant regional extinction in South America.

\section{Monimiophyllum callidentatum, sp. nov.}

Monimiophyllum callidentatum establishes the first fossil record of Monimiaceae in South America, at 52.2 Ma. Leaf morphological characters show that $M$. callidentatum most closely resembles the living, derived Australian species Wilkiea hugeliana and, secondarily, the closely related New Guinea species Kairoa suberosa (Table 5; Figure 8). The fossil is thus the only one known that may be closely related to Wilkiea. The similarity of $M$. callidentatum to $W$. hugeliana is further supported by the fact that the fossil matches most species in the Wilkiea clade, but not other clades, for the following characters: ratio of midvein width to secondary vein width, (high) acuteness of basal secondary veins, number of tooth orders (1), and tooth occurrence in the basal quarter of the blade (Figure 3). Molecular clock results estimated the age of the Australasian crown clade containing Wilkiea, Kairoa, and Kibara at ca. 16-19 Ma (16-38
Ma including 95\% confidence intervals), and the stem age of this clade (i.e., its divergence from the sister clade comprising Mollinedia, Grazielanthus, Macropeplus, Macrotorus, and Hennecartia) as only minimally older (Renner et al., 2010). In contrast, the presence of $M$. callidentatum in Eocene Patagonia shows that the Wilkiea lineage could be much older, inhabiting South America at $52.2 \mathrm{Ma}$, prior to the continent's final separation from Antarctica and Australia. However, without additional, comparable fossil occurrences, especially from Australia, it is not possible to further refine a scenario that explains the paleobiogeography of the Wilkiea clade or to identify the geographic origin of this lineage.

\section{Paleoecology and Associational Persistence}

Atherospermophyllum guinazui and Monimiophyllum callidentatum contribute a novel, probable understory component of basal angiosperms to the Eocene Patagonian landscape. Species of Atherospermataceae and Monimiaceae today are often understory shrubs and small trees (although they can penetrate the canopy, and some species are lianas), and the interpretation that the fossil species had low biomass, like the living taxa, is consistent with their extreme rarity in the fossil floras. One of the most visually striking features of both fossil species is their low leaf rank (of 2). Low vein density is associated with low leaf rank (Brodribb and Feild, 2010) and is considered characteristic of basal angiosperms, including many Laurales. Vein density has been shown to correlate directly to leaf hydraulic capacity and productivity (Boyce et al., 2009; Brodribb and Feild, 2010) because denser vein networks minimize the distance water must move through resistant leaf mesophyll to the stomata. Lower vein density, and thus lower efficiency and productivity, restricts plants to areas that are more shaded because they cannot meet the hydraulic demands imposed by full sun (Feild et al., 2011). This line of evidence has led to the interpretation that angiosperms originated as shrubs and small trees in rainforest understories (Feild et al. 2004, 2011). Atherospermophyllum guinazui exhibits a low vein density of 5.4 to $8.6 \mathrm{~mm} \mathrm{~mm}^{-2}$, and the single specimen of Monimiophyllum callidentatum also shows moderately low vein density, of $10.4 \mathrm{~mm} \mathrm{~mm}^{-2}$. These values are consistent with measured ranges of vein density for six extant Atherospermataceae and 21 extant Monimiaceae species, of 4.6 to $6.3 \mathrm{~mm} \mathrm{~mm}^{-2}$ and 3.1 to $10.2 \mathrm{~mm}$ $\mathrm{mm}^{2}$, respectively (Brodribb and Feild, 2010). The similarity of the fossil and extant vein density val- 
ues further supports a low-productivity, understory role for these Eocene taxa.

In many montane Australasian rainforest areas today, Atherospermataceae and Monimiaceae, including Daphnandra and Wilkiea, can be found growing (often together) beneath many of the same dominant taxa as those of Eocene Patagonia, including Agathis, Araucaria, Podocarpus, Akania, and diverse Cunoniaceae, Myrtaceae, and Proteaceae (e.g., Wilf et al., 2005, in press; González et al., 2007) and above the same fern genera (Todea, Dicksonia, Sticherus, Adiantum; Carvalho et al., 2013). Australian regions we have observed in the field (with R. Kooyman, Royal Botanic Gardens Sydney) to have particularly striking fossil-Patagonia to living-Australia similarities of this kind are the Border Ranges of northeastern New South Wales (e.g., Kooyman et al. 2012; Carvalho et al., 2013) and the higher elevations of the Atherton Tablelands. All these locations are ca. $11,000 \mathrm{~km}$ modern distance from Laguna del Hunco and Río Pichileufú.

\section{CONCLUSIONS}

The Atherospermataceae and Monimiaceae families (Laurales) exhibit a broad distribution across the Southern Hemisphere today, predominantly as shrubs and small trees in rainforests. Nevertheless, little is understood about how these widespread ranges developed. The fossil leaf species Atherospermophyllum guinazui (Berry) comb. nov. (Atherospermataceae) and Monimiophyllum callidentatum sp. nov. (Monimiaceae) from Eocene Patagonia contribute important records to their respective families and improve the resolution of their poorly known paleobiogeographic histories. The two fossil species show greatest morphological similarity to species in genera that are endemic to Australia today, especially Daphnandra (Atherospermataceae) and Wilkiea (Monimiaceae), respectively. Removal of $A$. guinazui from Laurelia eliminates yet another lineage that, historically, was thought to have persisted in Patagonia since the Eocene, and it increases the observed number of extinctions there. The striking resemblance of $M$. callidentatum to Wilkiea, which is considered from molecular clock estimates to be of relatively recent Australasian origin, suggests that the Wilkiea lineage may be much older than thought, predating the final breakup of Gondwana, and that it had a past distribution very different from its range today. Prior to this study, there were no known fossil occurrences likely to belong to the Wilkiea clade.
Today, species of Daphnandra and Wilkiea grow as shrubs or small trees in the understories of montane subtropical and tropical rainforests in northeast Australia. Due to the similar rarity and relatively low vein density of these fossil species, compared to their living counterparts, we infer that A. guinazui and $M$. callidentatum probably filled a similar niche as understory plants under tall, mixed angiosperm-conifer canopies in the Eocene volcanic rainforests of Patagonia. The ancient Patagonian forests had a floral composition remarkably similar to that of the living floras associated with Daphnandra and Wilkiea in Australia today. These results contribute to a growing body of evidence indicating that many lineages from the Patagonian Eocene floras are now extinct in South America, and that these floras (as described so far) show greatest affinity to living Australasian floras that preserve many of the ancient floral associations.

\section{ACKNOWLEDGMENTS}

We thank R. Kooyman for extensive discussions and related collaboration, including several field trips in Australia; J. Doyle for a very helpful review; M. Carvalho, M. Gandolfo, and R. Wilf for comments on earlier drafts; M. Donovan for significant editorial work; I. Escapa, T. Feild, R. Graham, and M. Patzkowsky for additional comments and insights; J. Conran for sharing prepublication data on Laurelia otagoensis; P. Puerta, R. Cúneo, E. Ruigómez, I. Escapa, L. Reiner, K. Johnson, S. Wing, B. Cariglino, C. González, R. Wilf, and J. Wingerath for extensive field and lab assistance; and the staff of the GH, MEL, CANB, and NSW herbaria for their invaluable help. This work was funded by the Krynine Scholarship Fund and the Center for Global Studies at Pennsylvania State University (CLK) and by NSF DEB-0919071, DEB0918932, and DEB-0345750 (PW). Early support came from National Geographic Society grant 7337-02, the University of Pennsylvania Research Foundation, and the Andrew W. Mellon Foundation (PW). This research partially completes requirements for a Masters in Geosciences for CLK at Pennsylvania State University, 2012.

\section{REFERENCES}

Angiosperm Phylogeny Group. 2009. An update of the Angiosperm Phylogeny Group classification for the orders and families of flowering plants: APG III. Botanical Journal of the Linnean Society, 161:105121. 
Aragón, E. and Mazzoni, M.M. 1997. Geología y estratigrafía del complejo volcánico piroclástico del Río Chubut medio (Eoceno), Chubut, Argentina. Revista de la Asociación Geológica Argentina, 52:243-256.

Archangelsky, S.1974. Sobre la edad de la tafoflora de la Laguna del Hunco, Provincia de Chubut. Ameghiniana, 11:413-417.

Berry, E.W. 1925. A Miocene flora from Patagonia. Johns Hopkins University Studies in Geology, 6:183-251.

Berry, E.W. 1928. Tertiary fossil plants from the Argentine Republic. Proceedings of the United States National Museum, 73:1-27.

Berry, E.W. 1935. The Monimiaceae and a new Laurelia. Botanical Gazette, 96:751-754.

Berry, E.W. 1938. Tertiary flora from the Río Pichileufú, Argentina. Geological Society of America Special Paper, 12:1-149.

Birkenmajer, K. and Zastawniak, E. 1989. Late Cretaceous-Early Neogene vegetation history of the Antarctic Peninsula sector. Gondwana break-up and Tertiary glaciations. Bulletin of the Polish Academy of Sciences, Earth Sciences 37:63-88.

Boyce, C.K., Brodribb, T.J., Feild, T.S., and Zwieniecki, M.A. 2009. Angiosperm leaf vein evolution was physiologically and environmentally transformative. Proceedings of the Royal Society B, 276:1771-1776.

Brodribb, T.J. and Feild, T.S. 2010. Leaf hydraulic evolution led a surge in leaf photosynthetic capacity during early angiosperm diversification. Ecology Letters, 13:175-183.

Carpenter, R.J. 2012. Proteaceae leaf fossils: phylogeny, diversity, ecology and austral distributions. The Botanical Review, 78:261-287.

Carpenter, R.J. and Jordan, G.J. 1997. Early Tertiary macrofossils of Proteaceae from Tasmania. Australian Systematic Botany, 10:533-563.

Carpenter, R.J., Jordan, G.J., Macphail, M.K., and Hill, R.S. 2012. Near-tropical Early Eocene terrestrial temperatures at the Australo-Antarctic margin, western Tasmania. Geology, 40:267-270.

Carvalho, M.R., Herrera, F.A., Jaramillo, C.A., Wing, S.L., and Callejas, R. 2011. Paleocene Malvaceae from northern South America and their biogeographical implications. American Journal of Botany, 98:1337-1355.

Carvalho, M.R., Wilf, P., Hermsen, E.J., Gandolfo, M.A., Cúneo, N.R., and Johnson, K.R. 2013. First record of Todea (Osmundaceae) in South America, from the early Eocene paleorainforests of Laguna del Hunco (Patagonia, Argentina). American Journal of Botany, v. 100 , p. 1831-1848. www.amjbot.org/content/100/9/ 1831.

Conran, J.G., Bannister, J.M., and Lee, D.E. 2013. Fruits and leaves with cuticle of Laurelia otagoensis sp. nov. (Atherospermataceae) from the early Miocene of Otago (New Zealand). Alcheringa, 37:1-14.
Doyle, J.A. and Endress, P.K. 2000. Morphological phylogenetic analysis of basal angiosperms: comparison and combination with molecular data. International Journal of Plant Sciences, 161:S121-S153.

Drinnan, A.N., Crane, P.R., Friis, E.M., and Pedersen, K.R. 1990. Lauraceous flowers from the Potomac Group (mid-Cretaceous) of eastern North America. Botanical Gazette, 151:370-384.

Dusén, P. 1908. Über die Tertiäre Flora der SeymourInsel. Wissenschaftliche Ergebnisse der Schwedischen Südpolar-Expedition 1901-1903, 3:1-27.

Eklund, H. and Kvaček, J. 1998. Lauraceous inflorescences and flowers from the Cenomanian of Bohemia (Czech Republic, Central Europe). International Journal of Plant Sciences, 159:668-686.

Ellis, B., Daly, D.C., Hickey, L.J., Johnson, K.R., Mitchell, J.D., Wilf, P., and Wing, S.L. 2009. Manual of Leaf Architecture. Cornell University Press, Ithaca, New York.

Feild, T.S., Arens, N.C., Doyle, J.A., Dawson, T.E., and Donoghue, M.J. 2004. Dark and disturbed: a new image of early angiosperm ecology. Paleobiology, 30:82-107.

Feild, T.S., Upchurch, G.R., Chatelet, D.S., Brodribb, T.J., Grubbs, K.C., Samain, M.-S., and Wanke, S. 2011. Fossil evidence for low gas exchange capacities for Early Cretaceous angiosperm leaves. Paleobiology, 37:195-213.

Florin, R. 1940a. The Tertiary fossil conifers of south Chile and their phytogeographical significance. Kungliga Svenska Vetenskapsakademiens Handlingar, 19:1-107.

Florin, R. 1940b. Die heutige und frühere Verbreitung der Koniferengattung Acmopyle Pilger. Svensk Botanisk Tidskrift, 34:117-140.

Foreman, D.B. and Whiffin, T. 2007. Atherospermataceae, p. 91-103. In Wilson, A.J.G. (ed.), Flora of Australia Volume 2: Winteraceae to Platanaceae ABRS/ CSIRO, Collingwood, Victoria.

Friis, E.M., Eklund, H., Pedersen, K.R., and Crane, P.R. 1994. Virginianthus calycanthoides gen. et sp. nov.a calycanthaceous flower from the Potomac Group (Early Cretaceous) of eastern North America. International Journal of Plant Sciences, 155:772-785.

Gandolfo, M.A., Dibbern, M.C., and Romero, E.J. 1988. Akania patagonica $\mathrm{n}$. $\mathrm{sp}$. and additional material on Akania americana Romero and Hickey (Akaniaceae), from Paleocene sediments of Patagonia. Bulletin of the Torrey Botanical Club, 115:83-88.

Gandolfo, M.A., Hermsen, E.J., Zamaloa, M.C., Nixon, K.C., González, C.C., Wilf, P., Cúneo, N.R., and Johnson, K.R. 2011. Oldest known Eucalyptus macrofossils are from South America. PLOS ONE, 6:e21084.

González, C.C., Gandolfo, M.A., Zamaloa, M.C., Cúneo, N.R., Wilf, P., and Johnson, K.R. 2007. Revision of the Proteaceae macrofossil record from Patagonia, Argentina. The Botanical Review, 73:235-266. 
Gottwald, H. 1992. Hölzer aus marinen Sanden des Oberen Eozän von Helmstedt (Niedersachsen). Palaeontographica B, 225:27-103.

Herendeen, P.S., Crepet, W.L., and Nixon, K.C. 1994. Fossil flowers and pollen of Lauraceae from the Upper Cretaceous of New Jersey. Plant Systematics and Evolution, 189:29-40.

Hermsen, E.J., Gandolfo, M.A., and Zamaloa, M.C. 2012. The fossil record of Eucalyptus in Patagonia. American Journal of Botany, 99:1356-1374.

Hickey, L.J. and Wolfe, J.A. 1975. The bases of angiosperm phylogeny: vegetative morphology. Annals of the Missouri Botanical Garden, 62:538-589.

Hill, R.S. and MacPhail, M.K. 1985. A fossil flora from rafted Plio-Pleistocene mudstones at Regatta Point, Tasmania. Australian Journal of Botany, 33:497-517.

Hyland, B.P.M., Whiffin, T., Christophel, D.C., Gray, B., and Elick, E. 2002. Australian Tropical Rain Forest Plants: Trees, Shrubs, and Vines. CSIRO, Melbourne (CD-ROM).

Iglesias, A., Zamuner, A.B., Poiré, D.G., and Larriestra, F. 2007. Diversity, taphonomy and palaeoecology of an angiosperm flora from the Cretaceous (Cenomanian-Coniacian) in southern Patagonia, Argentina. Palaeontology, 50:445-466.

Jordan, G.J. 1995. Early-middle Pleistocene leaves of extinct and extant Proteaceae from western Tasmania, Australia. Botanical Journal of the Linnean Society, 118:19-35.

Jordan, G.J., Carpenter, R.J., and Hill, R.S. 1998. The macrofossil record of Proteaceae in Tasmania: a review with new species. Australian Systematic Botany, 11:465-501.

Knappe, H. and Rüffle, L. 1975. Neue Monimiaceen im Santon des Subherzyn und ihre phytogeografischen Beziehungen zur Flora des ehemaligen GondwanaKontinents. Wissenschaftliche Zeitschrift der Humboldt-Universität Berlin, Mathematische-Naturwissenschaftliche Reihe, 24:493-499.

Kooyman, R., Rossetto, M., Allen, C., and Cornwell, W. 2012. Australian tropical and subtropical rain forest community assembly: phylogeny, functional biogeography, and environmental gradients. Biotropica, 44:668-679.

Kräusel, R. 1939. Ergebnisse der Forschungsreisen Prof. E. Stromer's in den Wüsten Ägyptens. IV. Die fossilen Floren Ägyptens. Abhandlungen der Bayerischen Akademie der Wissenschaften. MathematischNaturwissenschaftliche Abteilung, 47:1-140.

LaGabrielle, Y., Goddéris, Y., Donnadieu, Y, Malavielle, J., and Suarez, M. 2009. The tectonic history of Drake Passage and its possible impacts on global climate. Earth and Planetary Science Letters, 279:197211.
Lawver, L.A., Gahagan, L.M., and Dalziel, I.W.D. 2011. A different look at gateways: Drake Passage and Australia/Antarctica, p. 5-33. In Anderson, J.B. and Wellner, J.S. (eds.), Tectonic, Climatic, and Cryospheric Evolution of the Antarctic Peninsula. AGU, Washington, D.C.

Lee, D.E., Conran, J.G., Lindqvist, J.K., Bannister, J.M., and Mildenhall, D.C. 2012. New Zealand Eocene, Oligocene and Miocene macrofossil and pollen records and modern plant distributions in the Southern Hemisphere. The Botanical Review 78:235-260.

Lorence, D.H. 1985. A monograph of the Monimiaceae (Laurales) of the Malagasy Region (Southwest Indian Ocean). Annals of the Missouri Botanical Garden, 72:1-165.

Louvet, P. 1974. Sur trois bois fossiles du Tertiaire de Libye. Bulletin de la Société Botanique de France, 121:269-280.

Mädel, E. 1960. Monimiaceen-Hölzer aus den oberkretazischen Umzamba-Schichten von Ost-Pondoland (SAfrika). Senckenbergiana Lethaea, 41:331-391.

Mazzoni, M.M., Kawashita, K., Harrison, S., and Aragón, E. 1991. Edades radimétricas Eocenas. Borde occidental del Macizo Norpatagónico. Revista de la Asociación Geológica Argentina, 46: 150-158.

Money, L.L., Bailey, I.W., and Swamy, B.G.L. 1950. The morphology and relationships of the Monimiaceae. Journal of the Arnold Arboretum, 31:372-404.

Müller-Stoll, W.R. and Mädel, E. 1962. Fossil woods of Monimiaceae and Euphorbiaceae from the Upper Cretaceous Umzamba beds of East Pondoland, C. P. Transactions of the Geological Society of South Africa, 65:93-104.

Nishida, M. 1984. The anatomy and the affinities of the petrified plants from the Tertiary of Chile IV. Dicotyledonous woods from Quiriquina Island, near Concepción, p. 111-121. In Nishida, M. (ed.), Contribution to the Botany in the Andes I. Academia Science Books, Tokyo.

Nishida, M., Nishida, H., and Nasa, T. 1988. Anatomy and affinities of the petrified plants from the Tertiary of Chile V. The Botanical Magazine 101:293309

Philipson, W.R. 1987. A classification of the Monimiaceae. Nordic Journal of Botany, 7:25-29.

Peixoto, A.L. and Pereira-Moura, M.V.L. 2008. A new genus of Monimiaceae from the Atlantic coastal forest in south-eastern Brazil. Kew Bulletin, 63:137-141.

Pole, M. 2008. Dispersed leaf cuticle from the Early Miocene of southern New Zealand. Palaeontologia Electronica, 11.3.15A:117p, 1.5 MB; palaeo-electronica.org/2008_3/153/153.pdf

Poole, I. and Francis, J.E. 1999. The first record of fossil atherospermataceous wood from the upper Cretaceous of Antarctica. Review of Palaeobotany and Palynology, 107:97-107. 
Poole, I. and Gottwald, H. 2001. Monimiaceae sensu lato, an element of Gondwanan polar forests: evidence from the Late Cretaceous-Early Tertiary wood flora of Antarctica. Australian Systematic Botany, 14:207-230.

Privé-Gill, C., Gill, G.A., Thomas, H., Roger, J., Sen, S., Gheerbrant, E., and Al-Sulaimani, Z. 1993. Premier bois fossile associé aux primates Oligocènes du Dhofar (Taqah, Sultanat d'Oman). Comptes Rendus de l'Académie des Sciences Série 2, 316:553-559.

Pross, J., Contreras, L., Bijl, P.K., Greenwood, D.R., Bohaty, S.M., Schouten, S., Bendle, J.A., Röhl, U., Tauxe, L., Raine, J.I., Huck, C.E., van de Flierdt, T., Jamieson, S.S.R., Stickley, C.E., van de Schootbrugge, B., Escutia, C., and Brinkhuis, H. 2012. Persistent near-tropical warmth on the Antarctic continent during the early Eocene epoch. Nature, 488:73-77.

Pujana, R.R. 2009. Fossil woods from the Oligocene of southwestern Patagonia (Río Leona Formation): Atherospermataceae, Myrtaceae, Leguminosae and Anacardiaceae. Ameghiniana, 46:523-535.

Raven, P.H. and Axelrod, D.I. 1974. Angiosperm biogeography and past continental movements. Annals of the Missouri Botanical Garden, 61:539-673.

Renner, S.S. 1998. Phylogenetic affinities of Monimiaceae based on cpDNA gene and spacer sequences. Perspectives in Plant Ecology, Evolution and Systematics, 1:61-77.

Renner, S.S. 1999. Circumscription and phylogeny of the Laurales: evidence from molecular and morphological data. American Journal of Botany, 86:1301-1315.

Renner, S.S., 2005. Variation in diversity among Laurales, Early Cretaceous to Present. Kongelige Danske Videnskabernes Selskab Biologiske Skrifter, 55: 441-458.

Renner, S.S. and Takeuchi, W.N. 2009. A phylogeny and revised circumscription for Kairoa (Monimiaceae), with the description of a new species from Papua New Guinea. Harvard Papers in Botany, 14:71-81.

Renner, S.S., Foreman, D.B., and Murray, D. 2000. Timing transantarctic disjunctions in the Atherospermataceae (Laurales): evidence from coding and noncoding chloroplast sequences. Systematic Biology, 49:579-591.

Renner, S.S., Schwarzbach, A.E., and Lohmann, L. 1997. Phylogenetic position and floral function of Siparuna (Siparunaceae: Laurales). International Journal of Plant Sciences, 158:S89-S98

Renner, S.S., Strijk, J.S., Strasberg, D., and Thébaud, C. 2010. Biogeography of the Monimiaceae (Laurales): a role for East Gondwana and long-distance dispersal, but not West Gondwana. Journal of Biogeography, 37:1227-1238.

Romero, E.J. and Hickey, L.J. 1976. A fossil leaf of Akaniaceae from Paleocene beds in Argentina. Bulletin of the Torrey Botanical Club, 103:126-131.
Romero, E.J., Dibbern, M.C., and Gandolfo, M.A. 1988. Revisión de Lomatia bivascularis (Berry) Frenguelli (Proteaceae) del yacimiento de la Laguna del Hunco (Paleoceno), Pcia. del Chubut. Actas del IV Congreso Argentino de Paleontología y Bioestratigrafía, 3:125-130.

Rüffle, L.1965. Monimiaceen-Blätter im älteren Santon von Mitteleuropa. Geologie, 14:78-105.

Schodde, R. 1969. A monograph of the family Atherospermataceae R. Br. Unpublished PhD thesis, University of Adelaide, Adelaide, South Australia.

Schodde, R. 1970. Two new suprageneric taxa in the Monimiaceae alliance (Laurales). Taxon, 19:324-328.

Soltis, P.S. and Soltis, D.E. 2004. The origin and diversification of angiosperms. American Journal of Botany, 91:1614-1626.

Süss, H. 1960. Ein Monimiaceen-Holz aus der oberen Kreide Deutschlands, Hedycaryoxylon subaffine (Vater) nov. comb. Senckenbergiana Lethaea, 41:317-330.

Thorne, R.F. 1973. Floristic relationships between tropical Africa and tropical America, p. 27-47. In Meggers, B.J., Ayensu, E.S., and Duckworth, W.D. (eds.), Tropical Forest Ecosystems in Africa and South America: a Comparative Review. Smithsonian Institution Press, Washington D.C.

Tosolini, A.-M.P., Cantrill, D.J., and Francis, J.E. 2013. Paleocene flora from Seymour Island, Antarctica: revision of Dusén's (1908) angiosperm taxa. Alcheringa, 37:366-391.

Varela, A.N., Poiré, D.G., Martin, T., Gerdes, A., Goin, F.J., Gelfo, J.N., and Hoffmann, S. 2012. U-Pb zircon constraints on the age of the Cretaceous Mata Amarilla Formation, southern Patagonia, Argentina: its relationship with the evolution of the Austral Basin. Andean Geology, 39:359-379.

Whiffin, T. and Foreman, D.B, 2007. Monimiaceae. In Flora of Australia Volume 2: Winteraceae to Platanaceae, A.J.G. Wilson, ed., ABRS/CSIRO, Melbourne, $65-91$.

Wilf, P. 2012. Rainforest conifers of Eocene Patagonia: attached cones and foliage of the extant southeast Asian and Australasian genus Dacrycarpus (Podocarpaceae). American Journal of Botany, 99:562584.

Wilf, P., Escapa, I.H., Cúneo, N.R., Kooyman, R.M., Johnson, K.R., and Iglesias, A. in press. First South American Agathis (Araucariaceae), Eocene of Patagonia. American Journal of Botany, 101.

Wilf, P., Cúneo, R.N., Johnson, K.R., Hicks, J.F., Wing, S.L., and Obradovich, J.D. 2003. High plant diversity in Eocene South America: evidence from Patagonia. Science, 300:122-125.

Wilf, P., Johnson, K.R., Cúneo, N.R., Smith, M.E., Singer, B.S., and Gandolfo, M.A. 2005. Eocene plant diversity at Laguna del Hunco and Río Pichileufú, Patagonia, Argentina. American Naturalist, 165:634650. 
Wilf, P., Little, S.A., Iglesias, A., Zamaloa, M.C., Gandolfo, M.A., Cúneo, N.R., and Johnson, K.R. 2009. Papuacedrus (Cupressaceae) in Eocene Patagonia: a new fossil link to Australasian rainforests. American Journal of Botany, 96:2031-2047.

Zachos, J.C., Dickens, G.R., and Zeebe, R.E. 2008. An early Cenozoic perspective on greenhouse warming and carbon-cycle dynamics. Nature, 451:279-283.
Zamaloa, M.C., Gandolfo, M.A., González, C.C., Romero. E.J., Cúneo, N.R., and Wilf, P. 2006. Casuarinaceae from the Eocene of Patagonia, Argentina. International Journal of Plant Sciences, 167:12791289. 


\section{APPENDIX 1}

\section{Leaf Character Definitions}

Unless defined separately below, terminology for leaf scoring (Appendices 3,5 ) followed Ellis et al. (2009).

Midvein thickened at base: qualitative feature. The midvein is considered basally thickened if the midvein in the basal third of the leaf, especially near the insertion point of the petiole, is noticeably thicker than the midvein in the middle and apical portion of the leaf. (Appendix 2, Character 9; Appendix 4, Character 7)

Ratio of midvein $w: 2^{\circ} w$ : the width of the midvein divided by the width of a secondary vein. The width of the secondary vein is measured proximal to the midvein and perpendicular to the secondary vein course (Appendix 2, Character 11; Appendix 4, Character 8).

Basal secondaries acute: This is a measure of acuteness to the midvein of the basalmost pair of secondary veins is, relative to the superjacent pair of secondary veins. The measurement is the difference between the angle of the basalmost pair of secondary veins to the midvein, and the angle of the second pair of secondary veins to the midvein. When the angle measured is equal to zero, the basal secondary veins are not acute, and increasing angle measurements indicate increasing acuteness (Appendix 2, Character 12; Appendix 4, Character 10).

Proximity of secondary loop to margin: Measured as a percentage. The distance from the outermost point of a secondary vein (typically secondary veins in the medial portion of the blade are measured) divided by the total distance between the midvein and the margin, then multiplied by 100 . Both lengths are measured along the same line, which is perpendicular to the midvein (Appendix 2, Character 13; Appendix 4, Character 12).

Secondary loop shape: Qualitative feature. The secondary loop shape is scored 'even' if the superjacent and subjacent secondary veins in a secondary loop maintain a nearly constant distance from each other, until they loop near the blade margin. The secondary loop shape is scored 'cone' if the loop width decreases noticeably from the midvein to the blade margin (Appendix 2, Character 14; Appendix 4, Character 13).

Ratio of $2^{\circ}$ loop h:w: The maximum height of a secondary loop (measured from the intersection of a secondary with the midvein, to the apex of the secondary loop) divided by the maximum intercostal width of the secondary loop (measured between the intersection of the superjacent secondary vein and the midvein, to where a perpendicular line intersects the subjacent secondary) (Appendix 2, Character 15; Appendix 4, Character 14).

Tooth size: Measured as a percentage. Tooth size is the distance between the tooth sinus and the tooth apex, divided by the total distance of the tooth apex from the midvein, then multiplied by 100. Both lengths are measured along a single line, which is perpendicular to the midvein. The points at which the tooth apex and sinus occur are projected perpendicularly to this single line, and the length between these projected points is measured to calculate the percentage (Appendix 2, Character 24; Appendix 4, Character 22). 


\section{APPENDIX 2}

Characters used to score the fossil Atherospermophyllum guinazui comb. nov. and living Atherospermataceae, and explanation of coding. The character numbers given in this Appendix correspond to the first column in the scoring matrix (Appendix 3, below).

\begin{tabular}{|c|c|c|}
\hline Character & Character name & Coding \\
\hline 1 & laminar length:width ratio & Range \\
\hline 2 & leaf length & range $(\mathrm{mm})$ \\
\hline 3 & petiole swollen & $0=$ no, $1=$ yes \\
\hline 4 & base shape convex & $0=$ no, $1=$ yes \\
\hline 5 & apex shape straight & $0=$ no, $1=$ yes \\
\hline 6 & apex shape convex & $0=$ no, $1=y e s$ \\
\hline 7 & apex shape acuminate & $0=$ no, $1=y e s$ \\
\hline 8 & apex angle obtuse & $0=$ no, $1=$ yes \\
\hline 9 & midvein thickened at base & $0=$ no, $1=$ yes \\
\hline 10 & ratio of midvein $\mathrm{w}: 2^{\circ} \mathrm{w}$ & Range \\
\hline 11 & secondary attachment to midvein & $0=$ excurrent, $1=$ decurrent \\
\hline 12 & basal secondaries acute & max. angle (degrees) \\
\hline 13 & proximity of secondary loop to margin & range $(\%)$ \\
\hline 14 & secondary loop shape & $0=$ even, $1=$ cone \\
\hline 15 & ratio of $2^{\circ}$ loop h:w & Number \\
\hline 16 & number of $2^{\circ}$ loops & Number \\
\hline 17 & intersecondaries present & $0=$ no, $1=$ yes \\
\hline 18 & exterior tertiary loops & $0=$ weak, $1=$ strong \\
\hline 19 & exterior tertiary loop size/spacing & $0=$ irregular, $1=$ regular \\
\hline 20 & margin type & $0=$ entire, $1=$ toothed \\
\hline 21 & teeth per $\mathrm{cm}$ & Number \\
\hline 22 & number of tooth orders & Number \\
\hline 23 & second order teeth compound & $0=$ no, $1=$ yes \\
\hline 24 & tooth size & range $(\%)$ \\
\hline 25 & teeth occur in basal quarter of blade & $0=$ no, $1=$ yes \\
\hline 26 & principal vein branches from outermost tertiary & $0=$ no, $1=$ yes \\
\hline 27 & tooth accessory veins & $0=$ none, $1=$ conjunctal \\
\hline 28 & tooth shape cc/st & $0=$ no, $1=$ yes \\
\hline 29 & tooth shape cc/rt & $0=$ no, $1=$ yes \\
\hline 30 & tooth shape cc/fl & $0=$ no, $1=$ yes \\
\hline
\end{tabular}




\section{APPENDIX 3}

\section{Atherospermataceae Character Matrix}

Character data for the fossil Atherospermophyllum guinazui comb. nov. and living Atherospermataceae. Scores for living species are bold where they match or fully capture the fossil species' score or range.

\begin{tabular}{|c|c|c|c|c|c|c|c|c|}
\hline & 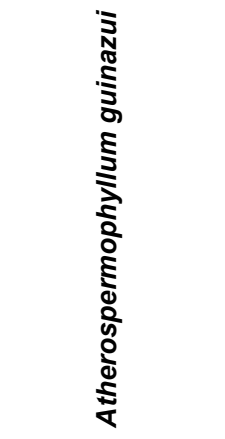 & 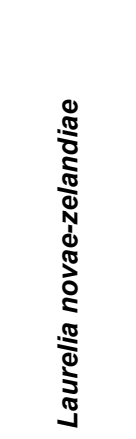 & 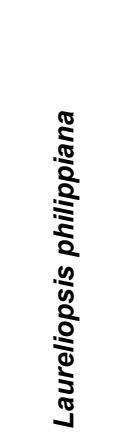 & 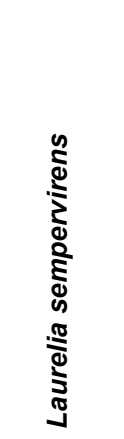 & 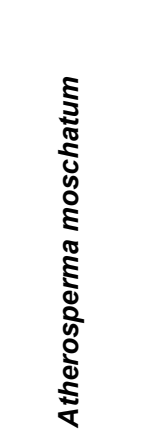 & 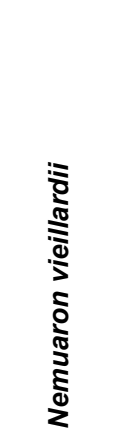 & 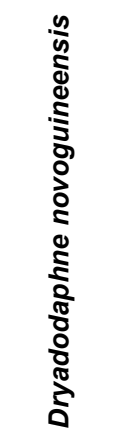 & 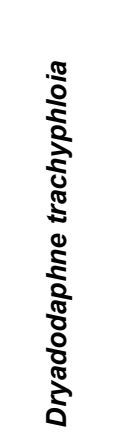 \\
\hline 1 & $2.17-3.29$ & $1.9-2$ & $1.62-3.3$ & $2.7-3.5$ & $2.8-3$ & $1.9-3$ & $2.9-3$ & $2.6-3.7$ \\
\hline 2 & $50-122$ & $35-76$ & $52-109$ & $53-114$ & $62-80$ & $41-71$ & $74-97$ & $48-170$ \\
\hline 3 & 1 & 1 & 1 & 1 & 1 & 1 & 1 & 1 \\
\hline 4 & 0,1 & 0 & 0 & 0 & 1 & 0 & 1 & 1 \\
\hline 5 & 1 & 0 & 1 & 1 & 1 & 0 & 0 & 0 \\
\hline 6 & 0 & 1 & 1 & 1 & 0 & 1 & 0 & 0 \\
\hline 7 & 0 & 1 & 0 & 0 & 0 & 1 & 1 & 1 \\
\hline 8 & 0 & 1 & 1 & 0 & 0 & 1 & 0 & 0 \\
\hline 9 & 1 & 1 & 1 & 1 & 0 & 1 & 1 & 1 \\
\hline 10 & $2.75-6.43$ & $1.88-4.24$ & $1.74-3.04$ & $3.04-5.42$ & $2.23-3.69$ & $3.25-6.21$ & $5.35-5.83$ & $2.12-5.56$ \\
\hline 11 & 1 & 1 & 1 & 1 & 0 & 1 & 1 & 1 \\
\hline 12 & 18 & 5 & 10 & 10 & 6 & 12 & 18 & 12 \\
\hline 13 & $4-24$ & $18-32$ & $24-27$ & $10-28$ & $9-13$ & $17-20$ & $17-27$ & $14-26$ \\
\hline 14 & 0,1 & 0 & 0 & 0 & 0 & 0 & 0 & 0 \\
\hline 15 & $1.47-4.33$ & $2.50-4.33$ & $3.60-5.40$ & $4.00-5.33$ & $3.50-5.00$ & $2.00-4.50$ & $1.86-3.20$ & $2.00-2.88$ \\
\hline 16 & 8-16 & 10-13 & $12-15$ & $10-16$ & $10-14$ & $11-15$ & 11-17 & $12-16$ \\
\hline 17 & 0,1 & 0 & 1 & 1 & 0 & 0 & 0 & 1 \\
\hline 18 & 0,1 & 0 & 1 & 1 & $\mathrm{n} / \mathrm{a}$ & $\mathrm{n} / \mathrm{a}$ & $0(?)$ & 1 \\
\hline 19 & 0,1 & 0 & 1 & 1 & $\mathrm{n} / \mathrm{a}$ & $\mathrm{n} / \mathrm{a}$ & 0 & 0 \\
\hline 20 & 1 & 1 & 1 & 1 & 0,1 & 1 & 1 & 1 \\
\hline 21 & $2-6$ & $3-5$ & $2-4$ & $2-4$ & $1-3$ & $2-6$ & $1-3$ & $1-3$ \\
\hline 22 & 1,2 & 2 & 2 & 2 & 2 & 2 & 1 & 1 \\
\hline 23 & $\mathrm{n} / \mathrm{a}, 1$ & 1 & 1 & 1 & 1 & 1 & $\mathrm{n} / \mathrm{a}$ & $\mathrm{n} / \mathrm{a}$ \\
\hline 24 & $3.63-11.93$ & $6.43-10.34$ & $5.27-14.87$ & $5.78-7.08$ & $7.35-16.13$ & $6.72-7.48$ & $4.19-6.07$ & $2.59-5.73$ \\
\hline 25 & 1 & 1 & 0,1 & 0,1 & 0,1 & 0,1 & 0,1 & 0 \\
\hline 26 & 1 & 1 & 1 & 1 & 0 & 0 & 1 & 1 \\
\hline 27 & 1 & 0 & 1 & 1 & 1 & 0 & 1 & 1 \\
\hline 28 & 0,1 & 0 & 1 & 0 & 1 & 0 & 0 & 0 \\
\hline 29 & 0,1 & 1 & 1 & 1 & 0 & 1 & 1 & 1 \\
\hline \multirow[t]{4}{*}{30} & 0,1 & 0 & 0 & 0 & 1 & 0 & 0 & 0 \\
\hline & Number of matches & 7 & 11 & 11 & 9 & 7 & 10 & 9 \\
\hline & Characters scored & 27 & 27 & 27 & 27 & 27 & 27 & 27 \\
\hline & $\%$ similarity & 25.93 & 40.74 & 40.74 & 33.33 & 25.93 & 37.04 & 33.33 \\
\hline
\end{tabular}


KNIGHT AND WILF: EOCENE LAURALES FROM PATAGONIA

Appendix 3 (continued).

\begin{tabular}{|c|c|c|c|c|c|c|}
\hline & 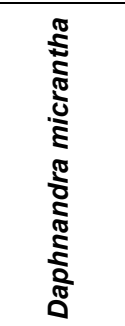 & 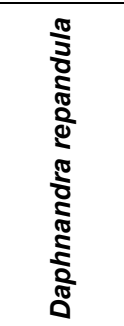 & $\begin{array}{l}\frac{\pi}{0} \\
\frac{\pi}{\pi} \\
\frac{\pi}{\pi} \\
\frac{\pi}{0} \\
\frac{0}{\pi} \\
\frac{\pi}{0} \\
\frac{0}{0}\end{array}$ & 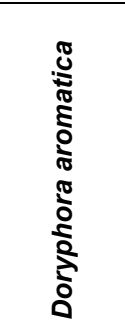 & 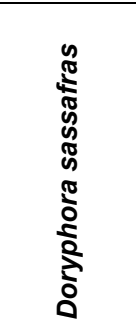 & \\
\hline 1 & $2.7-3$ & $3-3.7$ & $2.66-4.4$ & $2.2-3.1$ & $2.5-3.92$ & \\
\hline 2 & $65-156$ & 88-159 & $70-123$ & $58-139$ & $36-124$ & \\
\hline 3 & 1 & 0 & 0,1 & 1 & 1 & \\
\hline 4 & 1 & 1 & 0,1 & 0 & 0 & \\
\hline 5 & 1 & 1 & 0,1 & 1 & 0 & \\
\hline 6 & 0 & 0 & 0 & 0 & 0,1 & \\
\hline 7 & 1 & 1 & 1 & 1 & 1 & \\
\hline 8 & 0 & 0 & 0 & 0 & 0 & \\
\hline 9 & 0 & 1 & 1 & 0 & 1 & \\
\hline 10 & $2-3.32$ & $2.19-4.17$ & $2.18-4.22$ & $2.36-3.94$ & $3.12-4.4$ & no matches \\
\hline 11 & 1 & 1 & 0,1 & 1 & 0,1 & \\
\hline 12 & 12 & 10 & 13 & 8 & 19 & \\
\hline 13 & $11-24$ & $8-17$ & $16-25$ & $18-27$ & $12-18$ & no matches \\
\hline 14 & 1 & 1 & 1 & 0 & 0 & no matches \\
\hline 15 & $2.38-3.40$ & $2.41-4.14$ & $2.38-4.56$ & $1.80-1.88$ & $1.63-2.43$ & no matches \\
\hline 16 & $8-14$ & $9-13$ & $8-12$ & $9-15$ & $8-15$ & no matches \\
\hline 17 & 0 & 0 & 0,1 & 1 & 1 & \\
\hline 18 & 0 & 1 & 1 & 0 & 1 & no matches \\
\hline 19 & 0 & 0 & 0 & 0 & 0 & \\
\hline 20 & 1 & 1 & 1 & 1 & 1 & \\
\hline 21 & $2-4$ & $2-5$ & $2-6$ & $1-3$ & $1-3$ & \\
\hline 22 & 2 & 2 & 2 & 1 & 1,2 & \\
\hline 23 & 0 & 0 & 1 & $\mathrm{n} / \mathrm{a}$ & $\mathrm{n} / \mathrm{a}, 0$ & \\
\hline 24 & $6.58-8.5$ & $2.11-3.4$ & $4.65-12.82$ & $4.82-5.89$ & $5.13-11.99$ & no matches \\
\hline 25 & 1 & 1 & 1 & 0,1 & 0,1 & \\
\hline 26 & 1 & 1 & 1 & 1 & 1 & \\
\hline 27 & 1 & 1 & 1 & 1 & 1 & \\
\hline 28 & 1 & 1 & 0,1 & 0 & 1 & \\
\hline 29 & 1 & 1 & 1 & 1 & 1 & no matches \\
\hline \multirow[t]{4}{*}{30} & 0 & 0 & 0 & 0 & 0 & no matches \\
\hline & 9 & 9 & 15 & 9 & 12 & \\
\hline & 27 & 27 & 27 & 27 & 27 & \\
\hline & 33.33 & 33.33 & 55.56 & 33.33 & 44.44 & \\
\hline
\end{tabular}




\section{APPENDIX 4}

Characters used to score the fossil Monimiophyllum callidentatum sp. nov. and living Atherospermataceae, and explanation of coding. The character numbers given in this Appendix correspond to the first column in the scoring matrix (Appendix 5, below).

\begin{tabular}{|c|c|c|}
\hline & Character & Coding \\
\hline 1 & laminar L:W ratio & number \\
\hline 2 & leaf $L$ & range $(\mathrm{mm})$ \\
\hline 3 & petiole swollen & $0=$ no, $1=$ yes \\
\hline 4 & base shape convex & $0=$ no, $1=$ yes \\
\hline 5 & base angle acute & $0=$ no, $1=$ yes \\
\hline 6 & apex angle acute & $0=$ no, $1=y e s$ \\
\hline 7 & midvein thickened at base & $0=$ no, $1=y e s$ \\
\hline 8 & ratio of midvein $w: 2^{\circ} \mathrm{w}$ & range $(\%)$ \\
\hline 9 & secondary attachment to midvein & $0=$ excurrent, $1=$ decurrent \\
\hline 10 & basal secondaries acute & max angle (degrees) \\
\hline 11 & secondary loop strength & $0=$ weak, $1=$ strong \\
\hline 12 & proximity of secondary loop to margin & range $(\%)$ \\
\hline 13 & secondary loop shape & $0=$ even, $1=$ cone \\
\hline 14 & ratio of $2^{\circ}$ loop h:w & number \\
\hline 15 & number of $2^{\circ}$ loops & number \\
\hline 16 & intersecondaries present & $0=$ no, $1=$ yes \\
\hline 17 & exterior tertiary loops & $0=$ weak, 1 =strong \\
\hline 18 & exterior tertiary loop size/spacing & $0=$ irregular, $1=$ regular \\
\hline 19 & margin type & $0=$ entire, $1=$ toothed \\
\hline 20 & teeth per $\mathrm{cm}$ & number \\
\hline 21 & number of tooth orders & number \\
\hline 22 & tooth size & range $(\%)$ \\
\hline 23 & teeth occur in basal quarter of blade & $0=$ no, $1=y e s$ \\
\hline 24 & tooth accessory veins & $0=$ none, $1=$ conjunctal \\
\hline 25 & tooth shape cc/fl & $0=$ no, $1=$ yes \\
\hline
\end{tabular}




\section{APPENDIX 5}

\section{Monimiaceae Character Matrix}

Character data for living Monimiaceae and the single fossil of Monimiophyllum callidentatum, sp. nov. Scores for living species are bold where they match or fully capture the fossil species score or range.

\begin{tabular}{|c|c|c|c|c|c|c|c|c|c|}
\hline & 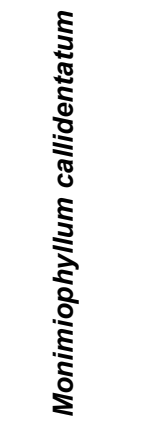 & 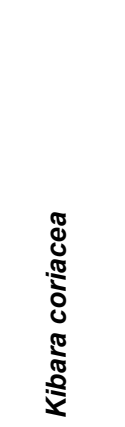 & 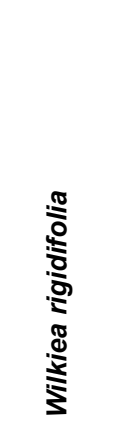 & 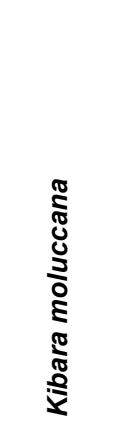 & 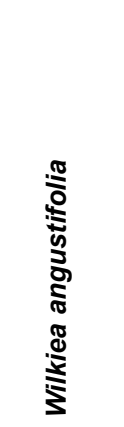 & 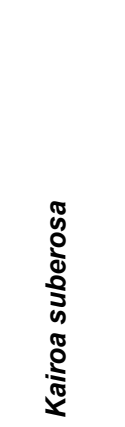 & 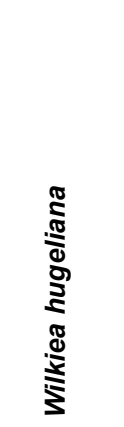 & 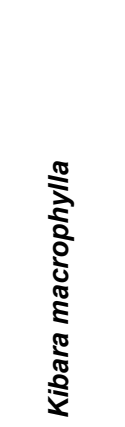 & 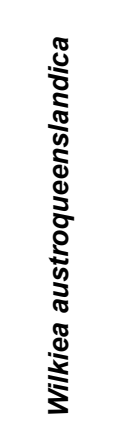 \\
\hline 1 & 4.56 & $2.31-2.42$ & $2.88-3.4$ & $2.53-3.17$ & $2.25-4.12$ & $2.86-3.28$ & $2.98-3.82$ & $2.83-3$ & $2.97-3.43$ \\
\hline 2 & 73 & $155-226$ & $161-221$ & $205-323$ & $70-142$ & $177-280$ & 49-119 & $63-201$ & $86-137$ \\
\hline 3 & 1 & 1 & 1 & 1 & 1 & 1 & 1 & 1 & 1 \\
\hline 4 & 1 & 0 & 1 & 0 & 1 & 1 & 1 & 1 & 1 \\
\hline 5 & 1 & 1 & 1 & 1 & 1 & 1 & 1 & 1 & 1 \\
\hline 6 & 1 & 0 & 0 & 1 & 1 & 1 & 1 & 1 & 1 \\
\hline 7 & 1 & 1 & 1 & 1 & 0 & 1 & 1 & 1 & 1 \\
\hline 8 & $2.32-3.04$ & $1.90-2.20$ & $2.29-3.76$ & $2.44-3.46$ & $2.75-3.83$ & $2.88-3.90$ & $2.20-3.00$ & $1.85-3.62$ & $2.16-4.45$ \\
\hline 9 & 0 & 1 & 0 & 1 & 1 & 1 & 0,1 & 1 & 0,1 \\
\hline 10 & $25-30$ & 11 & 23 & 21 & 25 & 27 & 45 & 22 & 10 \\
\hline 11 & 1 & 1 & 1 & 1 & 1 & 1 & 1 & 1 & 1 \\
\hline 12 & $8-13$ & $19-24$ & $7-14$ & $16-18$ & $15-21$ & $8-13$ & $16-33$ & $11-20$ & 16 \\
\hline 13 & 0 & 1 & 0 & 0 & 1 & 0 & 0 & 0 & 1 \\
\hline 14 & $1.43-1.6$ & $1.64-2.89$ & $1.7-2.06$ & $1.25-1.32$ & $1.14-1.23$ & $1.32-1.43$ & $1.07-1.89$ & $1.33-1.59$ & $1.55-2$ \\
\hline 15 & 19 & $9-11$ & 15 & 14 & $9-12$ & $15-24$ & $9-14$ & $12-14$ & $14-20$ \\
\hline 16 & 0 & 1 & 1 & 1 & 1 & 1 & 0 & 0 & 1 \\
\hline 17 & 0 & 0 & 1 & 1 & 1 & 0 & 0,1 & 1 & 1 \\
\hline 18 & 0 & 0 & 1 & 1 & 0 & 0 & 1 & 1 & 1 \\
\hline 19 & 1 & 0,1 & 0,1 & 0 & 1 & 1 & 1 & 0,1 & 1 \\
\hline 20 & $5-9$ & $1-2$ & $2-3$ & $\mathrm{n} / \mathrm{a}$ & $1-2$ & $1-2$ & $2-5$ & $1-2$ & $1-2$ \\
\hline 21 & 1 & 2 & 1 & $\mathrm{n} / \mathrm{a}$ & 1 & 1 & 1,2 & 2 & 2 \\
\hline 22 & $5.03-7.14$ & $1.64-2.17$ & $1.98-3.41$ & $\mathrm{n} / \mathrm{a}$ & $2.13-5.38$ & $4.16-6.92$ & $3.31-8.35$ & $3.11-5.98$ & $3.58-6.86$ \\
\hline 23 & 1 & 0,1 & 0,1 & $\mathrm{n} / \mathrm{a}$ & 1 & 1 & 0,1 & 1 & 0 \\
\hline 24 & 0 & 1 & 0 & $\mathrm{n} / \mathrm{a}$ & 1 & 0 & 1 & 1 & 1 \\
\hline \multirow[t]{4}{*}{25} & 1 & 1 & 1 & $\mathrm{n} / \mathrm{a}$ & 1 & 0 & 1 & 0 & 1 \\
\hline & $\begin{array}{c}\text { Number of } \\
\text { matches }\end{array}$ & 10 & 14 & 6 & 11 & 17 & 19 & 13 & 11 \\
\hline & $\begin{array}{l}\text { Characters } \\
\text { scored }\end{array}$ & 25 & 25 & 19 & 25 & 25 & 25 & 25 & 25 \\
\hline & $\%$ similarity & 40.00 & 56.00 & 31.58 & 44.00 & 68.00 & 76.00 & 52.00 & 44 \\
\hline
\end{tabular}


Appendix 5 (continued).

\begin{tabular}{|c|c|c|c|c|c|c|c|c|c|}
\hline & 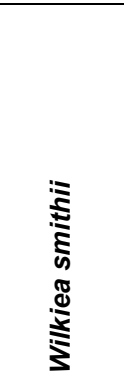 & 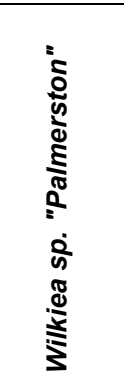 & 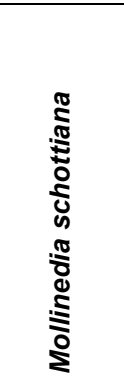 & 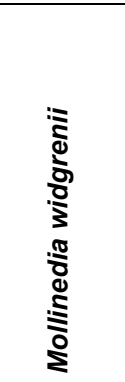 & 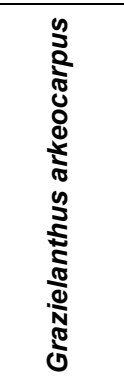 & 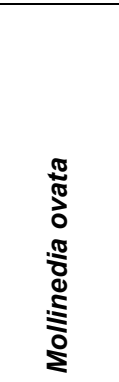 & 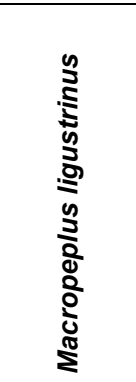 & 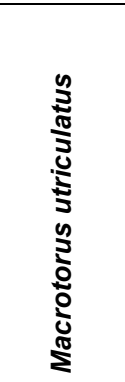 & 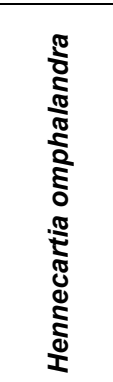 \\
\hline 1 & $2.26-3.36$ & $2.71-2.94$ & $2.13-2.71$ & $1.36-3.5$ & $2.29-2.86$ & 1.85 & $2-2.03$ & $2.7-2.78$ & $3.62-4.24$ \\
\hline 2 & $61-121$ & $103-114$ & $38-143$ & $53-182$ & $20-32$ & $135-157$ & $36-81$ & $178-186$ & $76-106$ \\
\hline 3 & 1 & 1 & 1 & 1 & 1 & 0 & 1 & 1 & 1 \\
\hline 4 & 1 & 0 & 0 & 1 & 0 & 0 & 1 & 0 & 1 \\
\hline 5 & 1 & 1 & 1 & 1 & 1 & 1 & 1 & 1 & 1 \\
\hline 6 & 1 & 1 & 1 & 1 & 1 & 0 & 1 & 1 & 1 \\
\hline 7 & 1 & 1 & 0 & 1 & 0 & 1 & 1 & 0 & 1 \\
\hline 8 & $3.75-4.40$ & $2.14-2.55$ & $1.88-2.06$ & $2.27-2.52$ & $1.50-3.14$ & $1.71-2.70$ & $2.55-3.44$ & $2.37-3.00$ & $1.92-3.50$ \\
\hline 9 & 1 & 1 & 0 & 0 & 0 & 1 & 0,1 & 0 & 1 \\
\hline 10 & 46 & 25 & 17 & 18 & 6 & 9 & 14 & 16 & 11 \\
\hline 11 & 1 & 1 & 0 & 0 & 0 & 1 & 1 & 1 & 1 \\
\hline 12 & $12-16$ & $18-23$ & $12-17$ & $9-13$ & $18-23$ & $9-14$ & $12-18$ & $18-21$ & $17-25$ \\
\hline 13 & 0 & 0 & 0,1 & 1 & 1 & 1 & 0 & 0,1 & 1 \\
\hline 14 & $1.18-1.71$ & $1.36-1.5$ & $1.57-1.75$ & $1.76-3.06$ & $1.6-2.33$ & $1.8-2.15$ & $1.60-1.96$ & $1.66-1.91$ & $1.25-1.44$ \\
\hline 15 & $16-18$ & $10-12$ & $7-12$ & $8-10$ & $7-10$ & 8 & $9-13$ & $8-9$ & $16-18$ \\
\hline 16 & 1 & 1 & $0-7$ & $0(?)$ & 1 & 1 & 0 & 1 & 0 \\
\hline 17 & 1 & 1 & 1 & 0 & 1 & 1 & 1 & 1 & 1 \\
\hline 18 & 1 & 1 & 1 & 0 & 1 & 0 & 0 & 1 & 0 \\
\hline 19 & 0 & 0 & 1 & 0,1 & 1 & 0,1 & 0,1 & 1 & 1 \\
\hline 20 & $\mathrm{n} / \mathrm{a}$ & $\mathrm{n} / \mathrm{a}$ & $1-3$ & $1-3$ & $5-10$ & $0-2$ & $1-3$ & 1 & $2-4$ \\
\hline 21 & $\mathrm{n} / \mathrm{a}$ & $\mathrm{n} / \mathrm{a}$ & 1 & 1 & 1 & 1 & 1 & 1 & 2 \\
\hline 22 & $\mathrm{n} / \mathrm{a}$ & $\mathrm{n} / \mathrm{a}$ & $2.84-6.00$ & $3.34-7.73$ & $2.36-5.23$ & $1.32-4.08$ & $4.93-11.31$ & $3.29-6.73$ & $5.94-8.69$ \\
\hline 23 & $\mathrm{n} / \mathrm{a}$ & $\mathrm{n} / \mathrm{a}$ & 0,1 & 0 & 0 & 0 & 0 & 0 & 1 \\
\hline 24 & $\mathrm{n} / \mathrm{a}$ & $\mathrm{n} / \mathrm{a}$ & 0 & 1 & 1 & 1 & 1 & 1 & 1 \\
\hline 25 & $\mathrm{n} / \mathrm{a}$ & $\mathrm{n} / \mathrm{a}$ & 1 & 0 & 1 & 1 & 0 & 0 & 1 \\
\hline & 10 & 7 & 13 & 13 & 10 & 7 & 14 & 8 & 13 \\
\hline & 19 & 19 & 25 & 25 & 25 & 25 & 25 & 25 & 25 \\
\hline & 52.63 & 36.84 & 52.00 & 52.00 & 40.00 & 28.00 & 56.00 & 32.00 & 52.00 \\
\hline
\end{tabular}


Appendix 5 (continued).

\begin{tabular}{|c|c|c|c|c|c|c|c|c|c|}
\hline & 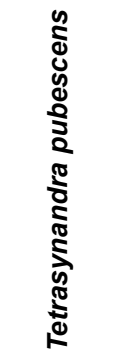 & 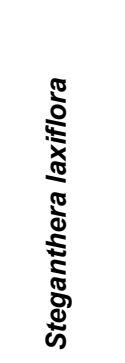 & 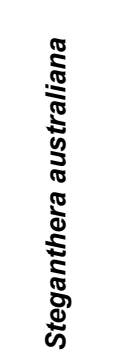 & 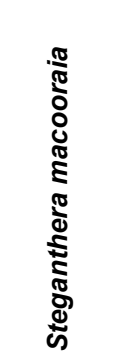 & 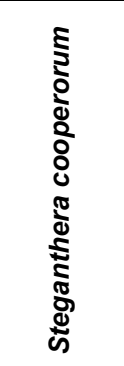 & 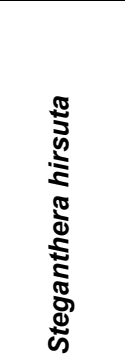 & 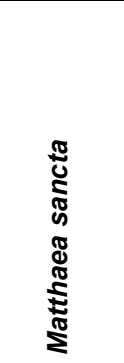 & 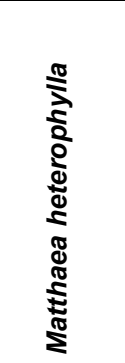 & 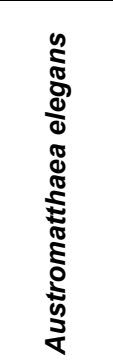 \\
\hline 1 & $2.93-4.21$ & $2.2-2.33$ & $3.33-3.4$ & $2.75-3.07$ & $3.23-5.1$ & $2.14-2.35$ & $2.77-2.96$ & $3.75-4.08$ & $3.46-5.03$ \\
\hline 2 & $59-167$ & $105-112$ & $130-136$ & $83-110$ & $51-126$ & $77-310$ & $80-119$ & $30-53$ & $83-176$ \\
\hline 3 & 1 & 1 & 1 & 1 & 1 & 1 & 1 & 1 & 1 \\
\hline 4 & 1 & 1 & 0 & 0 & 0 & 1 & 0 & 1 & 1 \\
\hline 5 & 1 & 0 & 1 & 1 & 1 & 0 & 1 & 1 & 0 \\
\hline 6 & 1 & 1 & 1 & 1 & 1 & 1 & 0 & 1 & 1 \\
\hline 7 & 1 & 1 & 1 & 1 & 0 & 1 & 1 & 1 & 1 \\
\hline 8 & $1.56-2.10$ & $2.06-2.58$ & $2.06-2.65$ & $3.33-3.48$ & $2.22-3.15$ & $1.73-2.14$ & $2.00-2.11$ & $2.5-4.16$ & $1.89-2.59$ \\
\hline 9 & 1 & 1 & 0 & 1 & 1 & 0 & 1 & 0 & 0 \\
\hline 10 & 14 & 10 & 11 & 9 & 16 & 10 & 12 & 21 & 0 \\
\hline 11 & 1 & 0 & 1 & 1 & 1 & 1 & 1 & 1 & 1 \\
\hline 12 & $13-26$ & $13-25$ & $15-25$ & $13-17$ & $8-16$ & $8-15$ & $10-17$ & $10-12$ & $8-18$ \\
\hline 13 & 1 & 1 & 0 & 0 & 0 & 1 & 1 & 1 & 0 \\
\hline 14 & $1.29-1.83$ & $1.48-2.56$ & $1.18-1.5$ & $1.75-1.86$ & $1.39-1.57$ & $1.17-1.52$ & $1.27-1.71$ & $1.13-1.4$ & $1.27-1.63$ \\
\hline 15 & $8-9$ & $6-7$ & $11-14$ & $12-14$ & $8-13$ & $10-12$ & $9-11$ & $12-13$ & $14-17$ \\
\hline 16 & 1 & 0 & 1 & 1 & 1 & 0 & 1 & 0 & 1 \\
\hline 17 & 1 & 1 & 0 & 0 & 1 & 1 & 1 & 1 & 0 \\
\hline 18 & 1 & 0 & 0 & 0 & 1 & 1 & 1 & 0 & 0 \\
\hline 19 & 1 & 0,1 & 0,1 & 0 & 0 & 0 & 0 & 0 & 1 \\
\hline 20 & $3-7$ & $1-2$ & $1-2$ & $\mathrm{n} / \mathrm{a}$ & $\mathrm{n} / \mathrm{a}$ & $\mathrm{n} / \mathrm{a}$ & $\mathrm{n} / \mathrm{a}$ & $\mathrm{n} / \mathrm{a}$ & $2-3$ \\
\hline 21 & 2 & 1 & 1 & $\mathrm{n} / \mathrm{a}$ & $\mathrm{n} / \mathrm{a}$ & $\mathrm{n} / \mathrm{a}$ & $\mathrm{n} / \mathrm{a}$ & $\mathrm{n} / \mathrm{a}$ & 1,2 \\
\hline 22 & $3.89-7.45$ & $2.42-5.64$ & $2.92-8.76$ & $\mathrm{n} / \mathrm{a}$ & $\mathrm{n} / \mathrm{a}$ & $\mathrm{n} / \mathrm{a}$ & $\mathrm{n} / \mathrm{a}$ & $\mathrm{n} / \mathrm{a}$ & $3.68-6.81$ \\
\hline 23 & 1 & 0 & 0 & $\mathrm{n} / \mathrm{a}$ & $\mathrm{n} / \mathrm{a}$ & $\mathrm{n} / \mathrm{a}$ & $\mathrm{n} / \mathrm{a}$ & $\mathrm{n} / \mathrm{a}$ & 1 \\
\hline 24 & 1 & 1 & 1 & $\mathrm{n} / \mathrm{a}$ & $\mathrm{n} / \mathrm{a}$ & $\mathrm{n} / \mathrm{a}$ & $\mathrm{n} / \mathrm{a}$ & $\mathrm{n} / \mathrm{a}$ & 0 \\
\hline \multirow[t]{4}{*}{25} & 1 & 1 & 1 & $\mathrm{n} / \mathrm{a}$ & $\mathrm{n} / \mathrm{a}$ & $\mathrm{n} / \mathrm{a}$ & $\mathrm{n} / \mathrm{a}$ & $\mathrm{n} / \mathrm{a}$ & 0 \\
\hline & 13 & 10 & 14 & 8 & 9 & 9 & 5 & 8 & 15 \\
\hline & 25 & 25 & 25 & 19 & 19 & 19 & 19 & 19 & 25 \\
\hline & 52.00 & 40.00 & 56.00 & 42.11 & 47.37 & 47.37 & 26.32 & 42.11 & 60.00 \\
\hline
\end{tabular}


Appendix 5 (continued).

\begin{tabular}{|c|c|c|c|c|c|c|c|c|c|}
\hline & 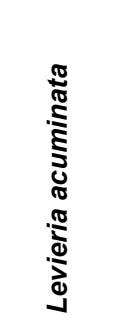 & 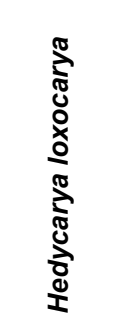 & 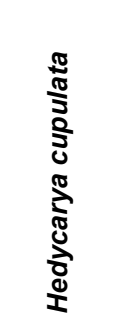 & 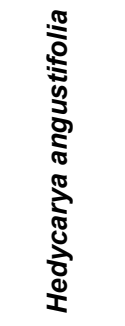 & 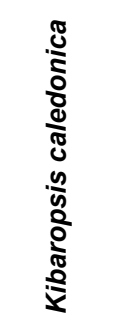 & 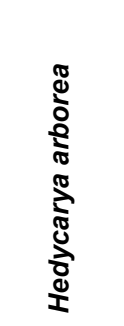 & 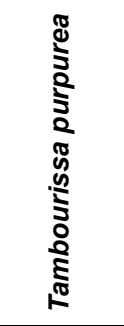 & 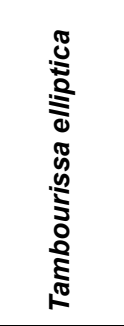 & 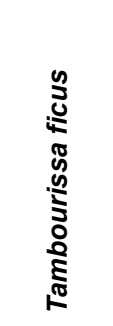 \\
\hline 1 & $3.43-3.58$ & $2.59-3.34$ & $2.47-3.42$ & $2.38-3.47$ & $2.71-4.52$ & $2.53-2.9$ & $2.5-2.61$ & $1.29-2$ & $2.24-2.98$ \\
\hline 2 & $72-136$ & $88-147$ & $65-116$ & $19-118$ & $113-233$ & $43-84$ & $35-99$ & $52-145$ & $83-176$ \\
\hline 3 & 0 & 1 & 1 & 1 & 1 & 1 & 1 & 0 & 0 \\
\hline 4 & 0 & 0 & 1 & 1 & 0 & 1 & 0 & 1 & 0 \\
\hline 5 & 1 & 1 & 1 & 1 & 1 & 1 & 1 & 1 & 1 \\
\hline 6 & 1 & 0 & 1 & 1 & 1 & 1 & 1 & 1 & 1 \\
\hline 7 & 1 & 1 & 1 & 1 & 1 & 1 & 0 & 0 & 0 \\
\hline 8 & $2.33-3.16$ & $1.53-4.52$ & $2.79-5.30$ & $2.48-4.75$ & $4.31-5.85$ & $3.69-4.76$ & $2.27-4.14$ & $3.28-4.83$ & $2.37-3.57$ \\
\hline 9 & 1 & 0 & 0 & 0,1 & 0,1 & 0 & 0 & 1 & 1 \\
\hline 10 & 12 & 20 & 20 & 23 & 0 & 8 & 16 & 14 & 11 \\
\hline 11 & 0 & 0 & 1 & 0 & 1 & 1 & 0 & 0 & 0 \\
\hline 12 & $8-15$ & $13-18$ & $13-27$ & $15-21$ & $9-14$ & $15-22$ & $8-17$ & $9-14$ & $11-17$ \\
\hline 13 & 1 & 1 & 0 & 1 & 0 & 0 & 0 & 0 & 0,1 \\
\hline 14 & $1.55-2.4$ & $1.47-2.06$ & $1.36-1.73$ & $1.3-1.5$ & $1.6-2$ & $1.5-2$ & $1.47-1.83$ & $1.6-2.15$ & $1.5-2.67$ \\
\hline 15 & $6-8$ & $8-10$ & $9-12$ & $8-12$ & $14-18$ & $10-15$ & $4-11$ & $10-19$ & $10-14$ \\
\hline 16 & 0 & 1 & 1 & 1 & 1 & 1 & 0 & 1 & 1 \\
\hline 17 & 0 & 0 & 1 & 0 & 1 & 0 & 0 & 0 & 0 \\
\hline 18 & 0 & 0 & 0 & 0 & 0 & 0 & 0 & 0 & 0 \\
\hline 19 & 1 & 0,1 & 0,1 & 1 & 0 & 1 & 0 & 0 & 0 \\
\hline 20 & $1-2$ & 1 & $1-2$ & $1-4$ & $\mathrm{n} / \mathrm{a}$ & $1-3$ & $\mathrm{n} / \mathrm{a}$ & $\mathrm{n} / \mathrm{a}$ & $\mathrm{n} / \mathrm{a}$ \\
\hline 21 & 1 & 1 & 1 & 2 & $\mathrm{n} / \mathrm{a}$ & 2 & $\mathrm{n} / \mathrm{a}$ & $\mathrm{n} / \mathrm{a}$ & $\mathrm{n} / \mathrm{a}$ \\
\hline 22 & $3.65-8.57$ & $5.29-10.8$ & $5.47-10.5$ & $2.23-12.1$ & $\mathrm{n} / \mathrm{a}$ & $6.03-7.86$ & $\mathrm{n} / \mathrm{a}$ & $\mathrm{n} / \mathrm{a}$ & $\mathrm{n} / \mathrm{a}$ \\
\hline 23 & 0 & 0 & 0 & 0 & $\mathrm{n} / \mathrm{a}$ & 0 & $\mathrm{n} / \mathrm{a}$ & $\mathrm{n} / \mathrm{a}$ & $\mathrm{n} / \mathrm{a}$ \\
\hline 24 & 0 & 1 & $0 ?$ & 1 & $\mathrm{n} / \mathrm{a}$ & 1 & $\mathrm{n} / \mathrm{a}$ & $\mathrm{n} / \mathrm{a}$ & $\mathrm{n} / \mathrm{a}$ \\
\hline 25 & 0 & 0 & 0 & 1 & $\mathrm{n} / \mathrm{a}$ & 0 & $\mathrm{n} / \mathrm{a}$ & $\mathrm{n} / \mathrm{a}$ & $\mathrm{n} / \mathrm{a}$ \\
\hline & 13 & 10 & 14 & 13 & 9 & 13 & 12 & 9 & 6 \\
\hline & 25 & 25 & 25 & 25 & 19 & 25 & 19 & 19 & 19 \\
\hline & 52.00 & 40.00 & 56.00 & 52.00 & 47.37 & 52.00 & 63.16 & 47.37 & 31.58 \\
\hline
\end{tabular}


Appendix 5 (continued).

\begin{tabular}{|c|c|c|c|c|c|c|c|c|c|}
\hline & 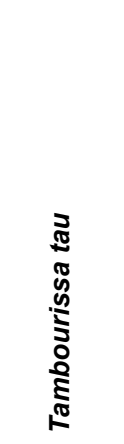 & 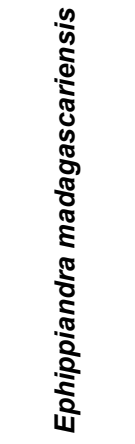 & 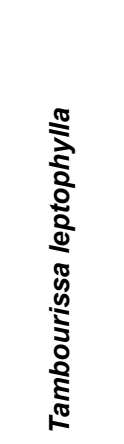 & 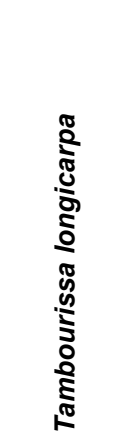 & 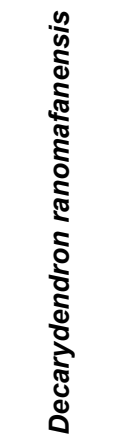 & 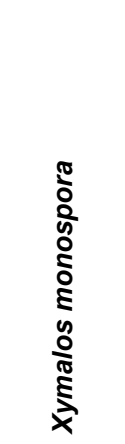 & 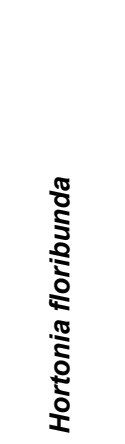 & 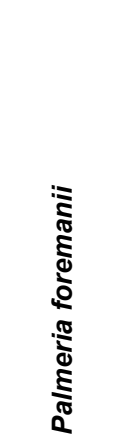 & 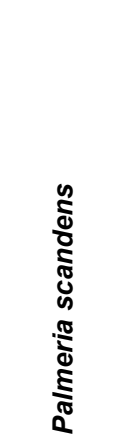 \\
\hline 1 & $3.17-3.87$ & $1.55-1.88$ & $1.5-1.87$ & $1.39-3.1$ & $1.89-2.16$ & $2.12-2.61$ & $1.5-3.11$ & $2.67-2.93$ & $1.81-3.31$ \\
\hline 2 & $165-298$ & $34-120$ & $60-230$ & $71-325$ & $36-82$ & $55-141$ & $39-109$ & 44-104 & $102-123$ \\
\hline 3 & 1 & 0 & 0 & 1 & 1 & 0 & 1 & 1 & 0,1 \\
\hline 4 & 1 & 1 & 1 & 1 & 1 & 0 & 1 & 1 & 1 \\
\hline 5 & 1 & 0 & 1 & 1 & 1 & 1 & 1 & 1 & 0,1 \\
\hline 6 & 1 & 0 & 1 & 1 & 1 & 1 & 1 & 1 & 0,1 \\
\hline 7 & 1 & 0 & 0 & 0 & 0 & 1 & 1 & 1 & 0 \\
\hline 8 & $2.61-4.49$ & $2.50-2.67$ & $2.71-4.67$ & $1.76-4.16$ & $2.40-3.33$ & $2.61-4.17$ & $1.79-2.46$ & $1.78-4.76$ & $2.00-2.61$ \\
\hline 9 & 0 & 0 & 0 & 0 & 0 & 0 & 0 & 0 & 0 \\
\hline 10 & 13 & 13 & 16 & 13 & 13 & 23 & 14 & 15 & 12 \\
\hline 11 & 0 & 1 & 0 & 0 & 1 & 1 & 0 & 1 & 0,1 \\
\hline 12 & $12-18$ & $15-30$ & $10-21$ & $16-26$ & $9-15$ & $12-17$ & $12-18$ & $15-18$ & $18-25$ \\
\hline 13 & 1 & 1 & 0,1 & 0,1 & 0 & 0 & 0,1 & 0 & 0 \\
\hline 14 & $1.73-2.24$ & $1.7-3.27$ & $1.38-2.13$ & $1.65-2.65$ & $1.5-2.33$ & $1.29-1.72$ & $1.14-1.76$ & $1.29-1.36$ & $1.23-2.21$ \\
\hline 15 & 8-15 & 6-8 & $9-13$ & 6-15 & 7-13 & 8-12 & 4-6 & $9-14$ & 10-14 \\
\hline 16 & 0 & 0 & 1 & 0 & 1 & 1 & 0 & 0 & 1 \\
\hline 17 & 0 & 0 & 0 & 1 & 0 & 1 & 0 & 1 & 1 \\
\hline 18 & 0 & 1 & 0 & 0 & 0 & 0 & 1 & 0 & 0,1 \\
\hline 19 & 0 & 1 & 0 & 1 & 0 & 0,1 & 0 & 0 & 0 \\
\hline 20 & $\mathrm{n} / \mathrm{a}$ & $1-3$ & $\mathrm{n} / \mathrm{a}$ & $1-2$ & $\mathrm{n} / \mathrm{a}$ & 1 & $\mathrm{n} / \mathrm{a}$ & $\mathrm{n} / \mathrm{a}$ & $\mathrm{n} / \mathrm{a}$ \\
\hline 21 & $\mathrm{n} / \mathrm{a}$ & 2 & $\mathrm{n} / \mathrm{a}$ & 1 & $n / a$ & 1 & $\mathrm{n} / \mathrm{a}$ & $\mathrm{n} / \mathrm{a}$ & $\mathrm{n} / \mathrm{a}$ \\
\hline 22 & $\mathrm{n} / \mathrm{a}$ & $6.09-11.32$ & $\mathrm{n} / \mathrm{a}$ & $8.87-14.42$ & $\mathrm{n} / \mathrm{a}$ & $4.88-6.52$ & $\mathrm{n} / \mathrm{a}$ & $\mathrm{n} / \mathrm{a}$ & $\mathrm{n} / \mathrm{a}$ \\
\hline 23 & $\mathrm{n} / \mathrm{a}$ & 0,1 & $\mathrm{n} / \mathrm{a}$ & 0 & $\mathrm{n} / \mathrm{a}$ & 0 & $\mathrm{n} / \mathrm{a}$ & $\mathrm{n} / \mathrm{a}$ & $\mathrm{n} / \mathrm{a}$ \\
\hline 24 & $\mathrm{n} / \mathrm{a}$ & 1 & $\mathrm{n} / \mathrm{a}$ & 1 & $\mathrm{n} / \mathrm{a}$ & 1 & $\mathrm{n} / \mathrm{a}$ & $\mathrm{n} / \mathrm{a}$ & $\mathrm{n} / \mathrm{a}$ \\
\hline \multirow[t]{4}{*}{25} & $\mathrm{n} / \mathrm{a}$ & 0 & $\mathrm{n} / \mathrm{a}$ & 0 & $\mathrm{n} / \mathrm{a}$ & 0 & $\mathrm{n} / \mathrm{a}$ & $\mathrm{n} / \mathrm{a}$ & $\mathrm{n} / \mathrm{a}$ \\
\hline & 9 & 8 & 9 & 12 & 11 & 11 & 11 & 12 & 8 \\
\hline & 19 & 25 & 19 & 25 & 19 & 25 & 19 & 19 & 19 \\
\hline & 47.37 & 32.00 & 47.37 & 48.00 & 57.89 & 44.00 & 57.89 & 63.16 & 42.11 \\
\hline
\end{tabular}


Appendix 5 (continued).

\begin{tabular}{|c|c|c|c|}
\hline & 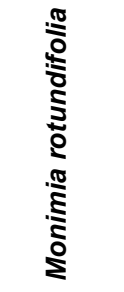 & 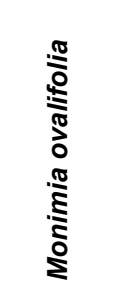 & 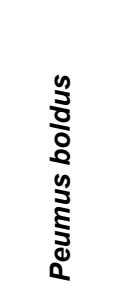 \\
\hline 1 & $1.35-1.52$ & $1.23-1.61$ & $1.71-2.32$ \\
\hline 2 & $47-146$ & $61-163$ & $24-65$ \\
\hline 3 & 1 & 1 & 1 \\
\hline 4 & 1 & 1 & 1 \\
\hline 5 & 0 & 0 & 1 \\
\hline 6 & 0 & 0 & 1 \\
\hline 7 & 1 & 1 & 1 \\
\hline 8 & $1.78-2.61$ & $2.20-2.57$ & $2.06-2.42$ \\
\hline 9 & 0 & 0 & 0 \\
\hline 10 & 5 & 5 & 22 \\
\hline 11 & 0 & 0 & 0 \\
\hline 12 & $15-20$ & $13-18$ & $12-23$ \\
\hline 13 & 0 & 0 & 0,1 \\
\hline 14 & $2.04-3.13$ & $2.18-4.27$ & $1.38-2.2$ \\
\hline 15 & $8-10$ & $9-11$ & $6-11$ \\
\hline 16 & 0 & 0 & 1 \\
\hline 17 & 1 & 1 & 0 \\
\hline 18 & 0 & 0 & 0 \\
\hline 19 & 0 & 0 & 0 \\
\hline 20 & $\mathrm{n} / \mathrm{a}$ & $\mathrm{n} / \mathrm{a}$ & $\mathrm{n} / \mathrm{a}$ \\
\hline 21 & $\mathrm{n} / \mathrm{a}$ & $\mathrm{n} / \mathrm{a}$ & $\mathrm{n} / \mathrm{a}$ \\
\hline 22 & $\mathrm{n} / \mathrm{a}$ & $\mathrm{n} / \mathrm{a}$ & $\mathrm{n} / \mathrm{a}$ \\
\hline 23 & $\mathrm{n} / \mathrm{a}$ & $\mathrm{n} / \mathrm{a}$ & $\mathrm{n} / \mathrm{a}$ \\
\hline 24 & $\mathrm{n} / \mathrm{a}$ & $\mathrm{n} / \mathrm{a}$ & $\mathrm{n} / \mathrm{a}$ \\
\hline \multirow[t]{4}{*}{25} & $\mathrm{n} / \mathrm{a}$ & $\mathrm{n} / \mathrm{a}$ & $\mathrm{n} / \mathrm{a}$ \\
\hline & 8 & 8 & 10 \\
\hline & 19 & 19 & 19 \\
\hline & 42.11 & 42.11 & 52.63 \\
\hline
\end{tabular}

